\title{
Contracting Out the Last-Mile of Service Delivery: Subsidized Food Distribution in Indonesia Faculty Research Working Paper Series
}

Abhijit Banerjee

Massachusetts Institute of Technology

\section{Rema Hanna}

Harvard Kennedy School

\author{
Jordan C. Kyle
}

International Food Policy Research Institute

\section{Benjamin A. Olken}

Massachusetts Institute of Technology

\section{Sudarno Sumarto}

National Team for the Acceleration of Poverty

\section{January 2016 \\ RWP16-001}

Visit the HKS Faculty Research Working Paper Series at:

https://research.hks.harvard.edu/publications/workingpapers/Index.aspx

The views expressed in the HKS Faculty Research Working Paper Series are those of the author(s) and do not necessarily reflect those of the John F. Kennedy School of Government or of Harvard University. Faculty Research Working Papers have not undergone formal review and approval. Such papers are included in this series to elicit feedback and to encourage debate on important public policy challenges. Copyright belongs to the author(s). Papers may be downloaded for personal use only. 


\title{
$\underline{\text { Acknowledgements }}$
}

This project was a collaboration involving many people. We thank Nurzanty Khadijah, Chaerudin Kodir, Lina Marliani, Purwanto Nugroho, Hector Salazar Salame, and Freida Siregar for their outstanding work implementing the project and Gabriel Kreindler, Wayne Sandholtz, and Alyssa Lawther for their excellent research assistance. We thank Mitra Samya, the Indonesian National Team for the Acceleration of Poverty Reduction (particularly Bambang Widianto, Suahasil Nazara, Sri Kusumastuti Rahayu, and Fiona Howell), and SurveyMetre (particularly Bondan Sikoki and Cecep Sumantri) for their cooperation implementing the project and data collection. This project was financially supported by the Australian Government through the Poverty Reduction Support Facility. Jordan Kyle acknowledges support from the National Science Foundation Graduate Research Fellowship under Grant No. 2009082932. This RCT was registered in the American Economic Association Registry for randomized control trials under Trial number AEARCTR-0000096. At least one co-author has disclosed a financial relationship of potential relevance for this research. Further information is available online at http://www.nber.org/papers/w21837.ack

The views expressed herein are those of the authors and do not necessarily reflect the views of the Harvard Kennedy School or the National Bureau of Economic Research.

(C) 2015 by Abhijit Banerjee, Rema Hanna, Jordan C. Kyle, Benjamin A. Olken, and Sudarno Sumarto. All rights reserved. Short sections of text, not to exceed two paragraphs, may be quoted without explicit permission provided that full credit, including () notice, is given to the source.

\begin{abstract}
$\underline{\text { Abstract }}$
Outsourcing government service provision to private firms can improve efficiency and reduce rents, but there are risks that non-contractible quality will decline and that reform could be blocked by vested interests exactly where potential gains are greatest. We examine these issues by conducting a randomized field experiment in 572 Indonesian localities in which a procurement process was introduced that allowed citizens to bid to take over the implementation of a subsidized rice distribution program. This led 17 percent of treated locations to switch distributors. Introducing the possibility of outsourcing led to a 4.6 percent reduction in the markup paid by households. Quality did not suffer and, if anything, households reported the quality of the rice improved. Bidding committees may have avoided quality problems by choosing bidders who had relevant experience as traders, even if they proposed slightly higher prices. Mandating higher levels of competition by encouraging additional bidders further reduced prices. We document offsetting effects of having high rents at baseline: when the initial price charged was high and when baseline satisfaction levels were low, entry was higher and committees were more likely to replace the status quo distributor; but, incumbents measured to be more dishonest on an experimental measure of cheating were also more likely to block the outsourcing process. We find no effect on price or quality of providing information about program functioning without the opportunity to privatize, implying that the observed effect was not solely due to increased transparency. On net, the results suggest that contracting out has the potential to improve performance, though the magnitude of the effects may be partially muted due to push back from powerful elites.
\end{abstract}




\section{INTRODUCTION}

A basic question in economics is whether the state should directly provide a public service or whether it should instead contract out the delivery to a private provider. In the seminal paper by Hart, Shleifer, and Vishny (1997, HSV henceforth), private contractors can potentially deliver better services-i.e. higher quality and/or a lower price-because governments can provide stronger incentives to private contractors than to their own employees. However, these stronger incentives could also push the contractors to lower quality below socially efficient levels in order to reduce costs. Therefore, in certain settings where noncontractible quality dimensions may be important—prisons is the example in HSV—public provision may be preferable to contracting private providers.

Even when contracting out has the potential to be effective, procuring the right contractor and arriving at the optimal contract has its own set of challenges. While competitive bidding processes are a natural mechanism for selecting the contract and the contractor, Spulber (1990) points out that the penalties on private parties who fail to fulfill contract terms may be constrained by bankruptcy protection, which may lead to an adverse selection problem that procurement agencies can partially counteract by focusing on firm reputations rather than simply awarding contracts to the lowest bidder. Bajari and Tadelis (2001) emphasize the challenge of getting the contract to cover all possible contingencies ex ante, resulting in a need for ex post renegotiation, which in turn is anticipated by the contractors and creates a scope for moral hazard. ${ }^{2}$ Bajari, McMillan, and Tadelis (2009) argue that as a result, with sufficiently complex contracts, competitive bidding may perform worse than simply negotiating with a single firm. All of this suggests that navigating the procurement processes involved in contracting out may be challenging, particularly when the government agents in charge of the privatization lack detailed expertise or competence in the intricacies of procurement.

There is, however, potentially an even bigger problem. All of the arguments so far about whether to privatize and if so how, presuppose that the decisions are being taken by agents acting in the public

\footnotetext{
${ }^{2}$ Bajari, Houghton and Tadelis (2011) show empirically with US data that such ex post renegotiation is both quantitatively important and anticipated by contractors.
} 
interest. However, the very services most in need of reform - those in which inefficiencies and rents are the highest - may be those in which existing vested interests have the strongest incentive to fight change (Krusell and Rios Rull 1996; Acemoglu and Robinson 2000), making it impossible to arrive at the decision that best serves the social interest. One can easily imagine this happening in a developing country context, where the goal is to outsource to eliminate corruption by a local official, but this also happens in developed ones: public sector unions, for example, vociferously oppose privatization, with substantial success (Hirsch 1995; McEntee 1987). Even if contracting out could deliver efficiency gains in theory, the ability of vested interests to block the process may limit successful privatizations to the cases where they are needed the least.

In this paper, we use a randomized control trial across 572 localities in Indonesia to investigate whether contracting out can work in light of these many issues- and whether it can overcome existing vested interests to be implemented in the first place. The service under consideration was the last-mile delivery of rice from Raskin, Indonesia's largest targeted transfer program (with an annual budget of over US\$1.5 billion). Under Raskin, eligible households can receive a monthly allocation of subsidized rice. As is typical in most developing countries, even though this is a central government program, the process of getting the rice from central government warehouses to beneficiaries -the "last mile" - is administered locally by either the locality head himself or someone he designates as social welfare coordinator. ${ }^{3}$

There is considerable room for program improvement. While the monthly co-pay is mandated to be Rp. 1600/kg of rice, the average buyer pays a mark-up of Rp. 658/kg above this. Substantial amounts of rice go missing (Olken 2006 estimates a lower bound of 18 percent missing; World Bank 2012 estimates about 50 percent), while much rice is also diverted to ineligible households. Thus, on net, eligible households only receive about one-third of their monthly intended subsidy. Moreover, citizens often complain about the poor quality of the rice and distribution process (e.g. location, timing).

\footnotetext{
3 This is often the case: India's work program (NREGA) is centrally dictated, but locally run, as is China's urban Di Bao program (Gustafsson and Quheng, 2011), which is among the world's largest transfer programs.
} 
However, is it not clear that outsourcing can improve the distribution. As in the HSV case, there are important non-contractible elements, such as the quality of the rice (lazy or incompetent distributors may accept low quality rice from the government warehouse without protest; nefarious contractors may sell good rice from the government to a private trader and substitute inferior rice instead), or delays (perhaps because the contractor does not have a truck of the right size). Running a procurement process that is focused on price might select contractors who will fall short on one of these quality dimensions. Moreover, procurement itself may be a challenge: there may be inadequate competition for a job of this size from people competent to do it, the citizens administering the procurement procedures may have limited experience, and local leaders obtaining rents from status quo may try to sabotage the process.

To examine these questions, in 191 randomly selected localities out of the 572, the central government introduced an alternative procedure involving competitive bidding for the right to be the Raskin distributor. The selection rule used to choose among bidders was not imposed externally, but instead a small committee chosen in a community meeting examined the bids and chose the winner. The incumbent local government distributor was also given the option to bid, providing the committee with the option to keep the status quo rather than outsourcing to the private sector. In short, this created a process that allowed citizens to compete with the government leaders for the job and for the local government to privatize the service if it thought this was a good decision.

We conducted two additional treatments to help us understand mechanisms through which the option for private provision may operate. First, to run the bidding process, one must explain how the current process works so that citizens could understand it and decide whether and how much to bid. Thus, if there is an effect, it could simply be due to this increase in transparency. To control for this effect, we also randomly assigned an additional 96 localities (out of the 572) to have the same meetings to describe the current processes, but not the actual bidding. This information-only treatment serves as a placebo comparison group that allows us to disentangle whether any observed effects are driven by allowing for private distributors to enter or simply arise from increased transparency. Second, to differentiate between the extensive margin of introducing any private sector competition from the 
intensive margin of additional competition, in 96 randomly selected localities of the 191 that were assigned to the bidding process, we instituted a policy encouraging a minimum of 3 bids.

Offering localities the opportunity to privatize led to substantial changes in the Raskin distribution. Areas that were assigned to the bidding process have, on average, more than 2 bidders for the job. Thus, there is, at least on paper, real competition, which, prima facie, could affect the distribution outcomes, even though, as it turned out, the eventual winner in about half the locations is the incumbent. Being assigned to have a bidding process led to a reduction in prices paid by households, with the markup falling by 7.3 percent relative to the information-only areas and 4.6 percent relative to pure control areas. Given that we find no effect of the information-only treatment on the price mark-up, this suggests that this observed effect was not simply driven by increased transparency.

We find no declines on other dimensions: the quantity of rice received did not change, nor did the quality of the distribution process (e.g. quality of the rice, time to pick up rice) decline. In fact, households actually report a higher quality of rice in the bidding group. Thus, the distributors were not cutting quality to compensate for the price changes. This is not just a reduction in rents - as HSV predict, there appears to be an efficiency gain, as the distributors present at endline in the bidding areas report much lower transportation costs (by about a third) than those in the information-only treatment.

These improvements are consistent with bidding committees making what appear to be broadly sensible choices among bids, prioritizing price but making tradeoffs consistent with choosing more experienced providers that can deliver. Comparing all winning and losing bids, the winners placed bids that had a 17 percent lower mark-up than the losers and they also promised to deliver the rice geographically closer to households. Being a trader is advantageous, with bidding committees being willing to pay about Rp. 250/kg (30 percent of the control mean) in terms of higher prices to choose a trader as the distributor. Similarly, having access to transportation (e.g. truck, boat) is worth about Rp. 140/kg. While the winners were more likely to require that households pay for the rice upfront (which could be construed as a negative bid attribute), the committee may have also chosen winners who realistically understood that upfront funds were needed in order to procure the rice from the warehouses; 
moreover, the winners were more likely to offer credit in their bids to offset the upfront payment requirement.

In short, it appears that the decision rule focuses primarily on price - 82 percent of locations with multiple bidders chose the low price bid - but deviates from it in directions that predicts higher credibility or lower costs (e.g. being a trader, owning transportation, asking for the money up front). One possible intuition is that, given their lower cost structure, these types of experienced providers may deliver a better quality conditional on the price that they bid. While we cannot conclusively say whether decision-makers are making the optimal choice, it is reassuring that there is no prima facie proof of obvious errors and that their decisions look sensible if one is trying to maximize some combination of low price and reliability. ${ }^{4}$

Increased competition on the intensive margin further improves outcomes. In localities that were randomly assigned to the "minimum number of bids" treatment, more people bid (2.74 bidders) than when there was no requirement (2.14 bidders). We find the largest decreases in price-markups in the places that had the minimum number of bids treatment compared to the bidding areas that did not, with no other observable declines in quality. We find that more bidders did not induce a change in efficiency, as measured by distributors' reported transportation costs; instead, more bidders seemed to reduce markups and profits. Interestingly, the bids themselves were not lower with more competition; rather, bidding committees appear to have followed a different decision making process, using the extra degrees of freedom generated by having more competition to choose bidders with relevant experience, who may have been more able to deliver on what they promised. This suggests that additional increases in competition could further improve outcomes, rather than worsen them as could occur in a winners curse situation. The fact that moving from approximately 2 to approximately 3 bidders made such a large difference is consistent with related results from the industrial organization literature, which suggest that the return to increased competition can come primarily from the entry of the second or third firm (e.g.

\footnotetext{
${ }^{4}$ One reason that we find a broadly positive result may be that the contracting problem here is simple in the sense of Bajari and Tadelis (2001). It also likely helps that there is very little sunk investment by either side in the contracting process; the contractor can simply walk away while the village can always opt to go back to the status quo ante.
} 
Bresnahan and Reiss 1991), and the magnitude is similar to that found in other contexts (see, e.g. Busso and Galiani 2014).

While offering localities the opportunity to privatize improved outcomes, the magnitudes were not overwhelming - at endline, only 17 percent of locations had been induced to change distributors, leading to an overall intent-to-treat estimate of about a 4.6 percent reduction in prices. A key question is why so few locations to switched. As the municipal head (or someone he designates) is the incumbent supplier, he may put road-blocks in the contracting if he obtains substantial rents from the process - either ex-ante by preventing the bidding from occurring or discouraging people to bid or ex-post by blocking the winning bidder from taking over the contract. Could this type of blocking by entrenched local elites explain why so few local governments switched and why the magnitudes of the gains were not larger?

While it is challenging to measure the rents directly, two pieces of evidence suggest that higher Raskin prices at baseline are consistent with larger rents, not just higher transportation costs. First, high baseline markups are strongly correlated to households' perceptions of the level of corruption of the municipal head and of the incumbent Raskin distributor. Second, this appears to be capturing more than just disgruntlement from been charged a high price. Following Fischbacher and Follmi-Heusi (2013) and Hanna and Wang (2014), we elicit an experimental measure of dishonesty from the distributors: we gave each of them a die, asked them to privately roll it 42 times, and to report the outcomes in order to receive a payment that was a multiple of the points rolled. In areas where the baseline markup was higher, baseline distributors reported higher than median dice scores, which is indicative of cheating on the task.

We find evidence of several offsetting effects from a high baseline price. On the one hand, high baseline prices see more private sector bidders entering (consistent with an upward sloping supply curve) and fewer incumbents winning. Indeed, this is actually an instance of a more general pattern: areas with low baseline satisfaction levels with Raskin are also more likely to complete the procurement process and to oust the incumbent during this process. On the other hand, there is some evidence that corrupt elites tried to block the process to protect their rents: localities in which the incumbent distributor scored highly on the dice-based cheating task are more likely to have the bidding process fail (either because it was 
blocked or because nobody bid), and conditional on it actually occurring, are more likely to choose the incumbent distributor. These results suggest that the presence of high rents leads to two partially offsetting effects: greater competition and more demand from the community to switch, but also entrenched elites fighting harder to protect their rents. On net, we show that the gains from the program were indeed highest in areas with high baseline rents - but that the pushback from local elites may be a reason why the effects were not quantitatively larger.

In short, giving localities the option to contract out delivery of government services by increasing competition within the system improves service delivery. However, while we observe a decline in the price mark-up, the gains were relatively modest and there was no increase in the total quantity of rice distributed (another important source of leakage). Simple changes to the process such as requiring a minimum number of bidders to further increase competitive pressures led to higher gains. But, the presence of entrenched local elites helps explain why the overall impact of outsourcing was not larger.

The paper proceeds as follows. Section II describes the setting, experimental design, and data. Section III explores the impact of the bidding process, the way that bidding committees made decisions, and the role of exogenously increasing the number of bidders. Section IV explores whether the process was able to overcome existing vested interests in areas with high rents at baseline. Section V concludes.

\section{Setting, Experimental Design and Data}

\section{A. Setting}

We examine Indonesia's subsidized rice program, known as "Raskin" (Rice for the Poor). First introduced in 1998, the program entitles 15.5 million low-income households to purchase $15 \mathrm{~kg}$ of rice per month at a co-pay price of Rp. 1,600 per kg (US\$0.15), or about one-fifth of the market price. This intended subsidy is substantial, equaling 4 percent of the beneficiary households' monthly consumption. It is Indonesia's largest permanent, targeted social assistance program, with an annual budget of over US\$1.5 billion intended to distribute 3.41 million tons of rice each year (Government of Indonesia, 2012). 
Although it is a national program, much of the day-to-day logistics for the "last mile" delivery to beneficiaries are handled at the local level. The central governmental logistics agency procures the rice and delivers it to its warehouses across the country, typically located in district capitals. Local governments (known as kelurahan in urban areas or desa (village) in rural areas) are responsible for picking up the their area's allotment of rice --on average, $5,550 \mathrm{~kg}$ of rice each month to be distributed to about 375 households - from the a central distribution point (either the warehouse itself or a central point located in the subdistrict capital), located, on average, about 7 kilometers from the center of the locality. The local government head, known as the lurah, typically appoints someone in the local government to run the distribution, usually either himself or someone he designates as social welfare coordinator. ${ }^{5}$

While picking up the rice at the warehouse, the local leader has to remit the co-payment for the rice to the central government. Once they transport the rice back to their locality, there is substantial heterogeneity in where they distribute it—at the lurah's office, at the homes of hamlet or neighborhood heads, or even transporting it directly to beneficiaries' houses. Local governments are not only responsible for the time and effort required to distribute the rice, but they also assume the transportation costs, which in control areas cost an average of Rp. 244,161 (US\$21) each month. ${ }^{6}$

In practice, Raskin faces a number of challenges. Beneficiaries complain that quality of rice is low. ${ }^{7}$ Rice may go missing at all stages in the distribution chain—from the central government to the subdistrict distribution point to within hamlets (Olken, 2006; World Bank, 2012). Moreover, the rice that arrives may be given to ineligible households rather than the eligible ones. On top of this, households often have to pay a higher co-pay price than the central government intends. As shown in Appendix Table 1, buyers paid an average, baseline mark-up of about Rp. 660 per kg (about a 40 percent mark-up). ${ }^{8}$

It is important to note that these facts do not necessary imply malfeasance: local governments

\footnotetext{
${ }^{5}$ The lurah is an appointed civil servant in urban kelurahan and an elected private citizen in rural desa.

${ }^{6}$ There is, however, regional heterogeneity in these costs. In some areas, sub-district or district governments help subsidize these transport costs; in other areas, the sub-district may also deliver the rice directly to the village.

${ }^{7}$ Anecdotally, people complain that Raskin rice is often crushed and mixed with small stones, which may be a way for corrupt officials to increase the weight of the rice. About 93 percent of eligible households report that the quality of rice in the market is higher than the quality of Raskin rice.

${ }^{8}$ There is much heterogeneity in the mark-up (Appendix Figure 1), with few households buying at the official rate.
} 
may be diverting rice to deserving, but ineligible households, or they may charge a higher co-pay for legitimate reasons, for example, to cover the transportation costs of distributing the rice. However, the distributors in our control group report transport costs that only account for about 12.4 percent of the price difference. Thus, it is likely that much of the higher price and missing rice is lost through corruption.

\section{B. Sample}

This project was carried out in 6 districts in Indonesia (2 each in the provinces of Lampung, South Sumatra, and Central Java). The districts are spread across Indonesia—specifically, on and off Java—in order to capture important heterogeneity in culture and institutions (Dearden and Ravallion, 1988). Moreover, to further capture heterogeneity across institutions, we ensured that the sample consisted of about 40 percent urban and 60 percent rural locations. Within these districts, we had originally randomly sampled 600 locations. Prior to conducting the randomization, we dropped 28 localities that were deemed too unsafe to send survey teams. Thus, the final sample comprised 572 localities. ${ }^{9}$

\section{Experimental Design}

Stratifying by geographic location and the previous experiments, we randomly assigned the 572 locations to one of three treatment assignments—-pure control, bidding, and information-only—as follows:

Pure Control: We randomly assigned 285 locations to the control group (see Appendix Table 2). These locations reflect the status quo distribution process detailed above, where the local government primarily assumes responsibility for local pick-up and distribution.

\footnotetext{
${ }^{9}$ Due to a constrained timeline for providing feedback into policy, we conducted the experiment in an area where we had previously conducted an experiment on an unrelated cash transfer program that is run by a different government ministry (see Alatas et al. (2012) and Alatas et al. (forthcoming). We also conducted a separate Raskin experiment on transparency (see Banerjee et al 2015). As we discuss below, we stratified the treatment assignments in this project by the previous experiments in order to ensure balance across the previous interventions.
} 
Bidding: We randomly assigned 191 localities to a process where private individuals or firms could bid for the right to become the official Raskin distributor, i.e. to purchase the rice from the national logistics agency at the distribution point, transport it to the locality, and sell the Raskin rice to households. The bidding process proceeded as follows: a facilitator from the district would arrive in the locality, accompanied by an official letter from the central government, to explain to the lurah that the location had been selected to have a procurement process for Raskin distribution. The lurah would then be asked to organize a meeting in which the current distributor would describe the current distribution process and then the procurement process would be announced. At this meeting, citizens were told that anyone who wanted to — from both within and outside the locality—could bid for the right to distribute Raskin by submitting a bidding form within 10 days. The bidding form was a standard one that was provided to the local government, which included, but was not limited to, the price that the prospective bidder would charge citizens, the process (e.g. where the rice would be distributed, whether the households would have to pay upfront), and the bidder's qualifications (e.g. access to credit, owning a truck). The central government insisted that households should receive their full allotment of rice, so the quantity of rice that the potential distributor would allow households to buy was not included on the forms. Bidders did not necessarily know the number of other bidders when they submitted and the bids remained sealed until the bidding meeting. Individuals were told that the winner would have the right to distribute Raskin for 6 months, with another meeting held at that time in which the committee would decide whether to continue with him, revert to previous distributor, or set up a new bidding process.

In addition, a small committee was formed during this organizational meeting to oversee the bidding process and monitor its outcomes. The committee included members of the independent local monitoring committee (the Lembaga Pemberdayaan Masyarakat, Agency for Community Empowerment, "LPM") charged with overseeing community development and improving the quality of local public services, neighborhood heads, informal community leaders, and Raskin beneficiaries. To avoid conflicts of interest, current distributors were excluded from being on this committee. 
Note three important details. First, in addition to spreading information about the bidding process via word of mouth from the meeting attendees, informational posters were strategically posted in the locality and the sub-district capital in order to advertise both inside and outside the locality. Second, the current distributor - generally, the lurah or another local government staff member — was also allowed to bid, and in fact, the current distributor bid in 66 percent of the cases where there was at least one bid.

Third, we randomized whether there was a minimum number of bids that was needed for the procurement process to commence. ${ }^{10}$ Specifically, in 96 randomly selected locations, we required a minimum of 3 bids, while there was no requirement in the remaining locations (Appendix Table 2). If three bids were not submitted by the deadline, it was extended by 10 days. If after the extension, there were still not enough bids, the process continued with the realized number of bidders. If more than five bids were submitted (which only happened in 7 locations), the committee chose only the best five to be presented at the meeting so that there would be sufficient time to discuss all of the bids.

After the window to submit bids, but before looking at the bids, the committee developed a set of criteria by which to select the winner. The committee was given some suggestions, including: proposed Raskin retail prices, distribution methods, pick-up locations for households, household payment methods, distributors' assets and capital ownership, projected costs of distribution, bidders' experience level, and bidders' overall character. However, the criteria were left open so that committee could set their own priorities for what constituted a good proposal. At this point, the committee also had the option to reject proposals that were not considered serious (11.8 percent of bids were rejected at this stage).

Next, each bidder presented his proposal to the bidding committee at a public meeting. Although the facilitator was present during the meeting to take notes, their participation was minimal and a committee representative led the meeting. During each presentation, the key proposal information was

\footnotetext{
${ }^{10}$ We also randomized two other aspects of the committee formation and function. First, we randomized whether we required that a third of the committee be female. Second, we randomized whether the facilitators suggested that the committee hold a follow-up meeting within three months to discuss the state of the distribution process. However, no follow-up or monitoring was done by the facilitators to ensure that the committee followed through with this meeting. Appendix Tables 4 and 5, respectively, provide results examining these changes.
} 
written on a large notepad that everyone could see to facilitate discussion. Bidders were allowed to improve upon their bids during the meeting in response to questions or in response to other bids.

After the presentations, the committee members privately scored each proposal according to their criteria and summed the proposal's scores to determine the winner. Each bid was scored with a 1-10 qualitative score on each dimension, so that committees de facto had substantial leeway in how they assessed various bids. The committees always had an odd number of members ( 3 or 5 ) to ensure no ties. They also had the option of rejecting all of the bids and reverting to the status quo if they deemed that none were of high enough quality. At the end, the lurah issued a letter establishing the winner as the official distributor for the next six months; this letter was also provided to relevant sub-district and district officials so that the winner could pay for and pick up the Raskin rice at the warehouse.

The facilitators returned to the locality about six month later. The current distributor made a presentation about the Raskin distribution process as it operated at that time and the committee discussed their views on the process. They also decided whether or not to extend the new winner (if there was one), choose a new distributor, or revert back to the old process.

Information-Only: The bidding process naturally provides greater transparency: one must provide information about the distribution process, so that potential bidders can decide whether to participate and, if so, provide realistic bids. Thus, if one observes an effect, it could simply be due to greater transparency.

To control for the information effects of the bidding treatment, we also randomly selected 96 locations for an information-only treatment, where a community facilitator coordinated with the lurah to set up the organizational meeting where current process was described. At that meeting, a similarlycomposed committee was also tasked with discussing and monitoring the process, following the same procedures as in the bidding treatment. Again, a follow-up meeting was also carried out at the end of 6 months to again provide information on the distribution process (i.e. at the same time as the re-evaluation meeting of the bidding treatment). This treatment was, therefore, identical to the bidding treatment in terms of providing information to citizens and organizing a committee who could potentially monitor the 
process, but did not include the bidding. ${ }^{11}$ We therefore use this treatment as a comparison group for the bidding treatment to isolate the pure effect of the potential to outsource from increased transparency. ${ }^{12}$

\section{Randomization Design, Timing, and Data}

Appendix Table 2 shows the number of locations randomly assigned to each treatment. We stratified by 6 geographic strata (districts) and the previous experimental treatments.

The timeline was as follows (Appendix Figure 2): in April-July 2013, after the baseline survey was completed for the entire sub-district, both treatments were conducted. During the following six months, facilitators maintained a call center to address any on-the-ground issues; only 17 calls were ever received. In January-February 2014, after the endline survey was completed in that sub-district, the facilitators returned to hold the follow-up meetings.

\section{E. Data Collection}

All surveys were conducted by SurveyMeter, an established independent survey organization. Two household surveys serve as our baseline, one conducted in October and November 2012 and one in April and May 2013. Each survey was conducted in a separate randomly-selected sub-unit (RW) within the locality. In total, across both survey waves, we randomly sampled between 15 and 19 households in each locality, for a total of 10,277 households. ${ }^{13}$ We surveyed the households on their background and their experiences with Raskin. In addition, at the time of each baseline survey, we also interviewed the lurah.

\footnotetext{
${ }^{11}$ As in the bidding process, we also randomly allocated half of the villages in this treatment to have a third of the committee be female, and for half to be encouraged to hold a follow-up meeting at three months on their own (without any facilitators, etc.) to discuss the state of the distribution. Appendix Tables 4 and 5 provide these results. ${ }^{12}$ A potential concern is that a bidding meeting might be more interesting, and hence draw more attention, than an information-only meeting. Appendix Table 19 compares what happened at the information only and bidding meetings, and shows that they while the meetings were not identical, they were broadly comparable in terms of intensity of activity, as measured by meeting length, number of people attending, and number of questions / comments. Specifically, information-only meetings were slightly shorter than bidding meetings (1.58 hours vs. 1.74 hours, so bidding meetings were 9.6 minutes longer on average), but had slightly more participants (28.5 vs 21.7 ) and slightly more questions/comments (6.5 questions in information meetings vs. 4.3 in bidding meetings).

${ }^{13}$ We oversampled households on the list of households eligible for the Raskin program to ensure adequate representation of these types of households in the survey. There are more households in baseline than in endline as the baseline was used for other purposes (Banerjee et al 2015).
} 
In December 2013 and January 2014, just before the six month follow-up meetings were held in the treatment locations, an endline survey took place in which we interviewed 6 randomly-selected households from each of the two baseline surveys (12 households per location), for a total of 6,864 households. As in the baseline surveys, we also surveyed the lurah.

At the time of the endline, we also conducted a "distributor survey" in order to better understand who was selected by the bidding process. We interviewed all then-current Raskin distributors. In the bidding and information locations, we also interviewed the old distributor (if different than the currently active distributor), as well as the winner in the bidding locations (if different than the current, which could occur, for example, if the winner was denied permission to distribute or quit). In the bidding locations, we also randomly selected one losing candidate and interviewed him as well. In this survey, we gathered professional information on all candidates (e.g. tested their ability, asked about their management experience, etc.) and asked information about the distribution process if they were involved in it.

As part of this distributor survey, we also conducted a modified version of the dice-based dishonesty task in Fischbacher and Follmi-Heusi (2013). The task involves the survey respondent tossing a die 42 times, away from the prying eye of the surveyor, and recording the number on the face of the die on each roll. Participants would then receive Rp. 100 (US\$0.01) for each die point that they record. The idea is that any given person can cheat without being detected, but that one can detect cheating statistically by looking for scores that are higher than would be predicted by chance. Hanna and Wei (2014) show that this task is correlated with real-world corruption: they conducted this task with government nurses in India and show that a high score is correlated with fraudulent absenteeism.

Finally, we have access to administrative data from the bidding forms filled out by prospective bidders and facilitators of the bidding process. 


\section{F. $\quad$ Experimental Validity}

Appendix Table 6A provides a check on the randomization of locations to the control, bidding and information treatments. We provide the difference, conditional on strata, between bidding and pure control (Column 5), information-only and pure control (Column 6), and bidding and information-only (Column 7). Of the 45 differences that we estimate between the groups, only 5 (11 percent) are significant at the 10 percent level, which is consistent with chance. The joint p-value across all 15 variables is 0.23 , 0.50, and 0.20 in Columns 5-7, respectively. In Appendix Table 6B, we also conduct a randomization check on required minimum bids versus open bidding process. Again, the treatments appear balanced across the treatments with none of the individual differences statistically significant at the 10 percent level with a p-value for a joint significance test of 0.71 .

\section{G. Descriptive Statistics on the Bidding Process}

We begin in Figure 1 by plotting the flow of the 191 treatment locations through the bidding process to document how it was implemented. We provide the average price markup of Raskin rice reported in the household surveys at both baseline and endline for the treatment areas at each step in the process.

The flowchart highlights two key descriptive facts: First, almost all - 185 out of 191 - of locations randomized to the bidding treatment conducted the procurement processes, though 20 received no bids and reverted back to the status quo. However, of the 165 treatment locations that received at least 1 bid, 86 (52 percent) selected the original distributor.

Second, the baseline markup seems to be an important predictor of the bidding process outcomes. There appears to be more competition in places with higher markups: in places where there were no bidders, the baseline price markup averaged only Rp. 370; the baseline price markup is then monotonically increasing in the number of bidders all the way to 4 bidders, where it averaged Rp. 766. A new individual won in places with average baseline markup of Rp. 754, compared to Rp. 638 in places that selected the incumbent. However, there is some evidence that ex-post blocking behavior from local leaders occurs when there are greater rents: the 6 locations where the winner was blocked from 
distributing by the lurah or subdistrict had a baseline price almost double the average. The fact that the baseline price predicts the number of bidders, rejecting the old bidder, and ex-post blocking by local elites suggests that the price may be a good proxy for the high rents (we discuss more direct evidence on this point in Section IV). Though these descriptive statistics do not control for regional differences, other characteristics, etc., they are suggestive, and we explore these issues in more detail below.

Table 1 presents descriptive statistics on the bidding process. In Column 1, we present the overall mean, while in Columns 3 and 5, respectively, we present the means for locations randomly assigned either to the open process or to having a minimum number of bids for the process to occur. In Column 7 , we present the p-value of the difference of means across the open and minimum bids.

Citizens did bid for the distribution rights (Panel A). On average, we observe 2.43 bids placed, with 2.16 passing the initial selection and thus presented at the meeting. However, the process may have been dominated by the opinions of a few, particularly the elites (Panel B of Table 1 ). ${ }^{14}$ On average, we observed about 22 individuals at the bidding meetings (the average population size per location is 1,299 households). Local leaders comprised a fair share of the participants, with about 9 of them attending, on average. About 8 of the meeting participants claimed to be Raskin beneficiaries. The facilitators reported that relatively few people spoke at the meetings, with no discussion from the crowd in 9 percent of cases and with less than 10 percent of attendees talking at 43 percent of the meetings (Panel C). In only 3 percent of the meetings did they report that more than half of the crowd participated.

Requiring a minimum number of bids led to more legitimate bids considered at the meeting, but did not change the probability of selecting a new distributor (Panel A). There were 2.74 bids in locations randomized to the minimum bid treatment as opposed to 2.14 without the requirement; this difference is significant with a p-value of 0.01 . One worry is that to fulfill the requirement, we would observe more bids that would fail the initial quality screening process, but this was not the case: in the minimum

\footnotetext{
${ }^{14}$ In Appendix Figures 3, we present reasons reported by the winners and losers, respectively, on their outcomes. The three biggest reasons that winners attributed their success were their reputation, support from village leaders, and their level of commitment (Panel A). On the other hand, the top reasons for losses were high purchase price and lack of support from village leaders (Panel B). This is also suggestive that the process may have been influenced by the local officials, whom the process was designed to circumvent or place pressure upon to improve.
} 
number of bids areas, we observe an increase in bids that pass the screen (2.44 relative to 1.88; p-value 0.01). There were more meetings with no discussion (15 percent in the minimum bid versus 3 percent otherwise), but this may have been due to the fact that there were more proposals to present. On net, a new distributor won in 45 percent of minimum number of bids areas as opposed to 51 percent in the open bidding locations; this difference, however, is not significant at conventional levels (p-value of 0.49).

\section{DOES CONTRACTING OUT IMPROVE OUTCOMES?}

\section{A. Who is in charge of distribution?}

In Table 2, we examine whether the Raskin distributor characteristics changed as a result of the bidding treatment. Specifically, we estimate the following regression:

$$
y_{i s}=\alpha_{s}+\beta(B I D D I N G \text { or INFO })_{i s}+\gamma B I D D I N G_{i s}+\epsilon_{i s}
$$

where $i$ represents a study location and $s$ represents one of our geographic strata. We include an indicator variable for whether there was either the bidding or information-only treatment ((BIDDING or INFO $\left.)_{i s}\right)$ and an indicator variable for just the bidding treating $\left(B I D D I N G_{i s}\right)$. Thus, the coefficient $\gamma$ captures how the bidding locations differ from those that received only the information-only (i.e. placebo) treatment and is thus the key coefficient of interest. The dependent variable in each column is a different characteristic of the distributor at endline (approximately six months after the intervention); this specification, thus, captures the net intent-to-treat effect of the treatment in practice, including the fact that bidding may not always have been carried out, that distributors may naturally change over time, and that winning bidders may be blocked, resign, or be otherwise forced out. We also report the p-value of the difference of the bidding treatment against the pure control group (row labeled "Bidding = Ctl”).

Six months after the bidding process, locations that were assigned to the bidding treatment were substantially more likely to have a new distributor relative to the other groups (Table 2, Panel A). Specifically, the distributor in the bidding areas was 17 percentage points—or 21 percent—less likely to have had Raskin responsibilities prior the intervention than the information-only group (Column 1), and about 20 percentage points more likely relative to the pure controls. 
The remaining columns explore the identity of who the distributor was. In the pure control group, almost 85 percent of the distributors were a local official, hamlet official, or the spouse of one (Columns 2, 3, and 4). In the bidding group compared to the pure control group, local leaders were significantly less likely to be in charge (Column 2), but their spouses/relatives and hamlet level-leaders were then more likely to be in charge (Columns 3 and 4); thus, overall elite participation after the bidding process was not greatly different than in the pure control group. Interestingly, this same pattern was occurring in the information-only group as well, and while the effects are qualitatively bigger in the bidding group than the information-only group, the differences are not statistically significant. This suggests that some of the change in leadership may have been due to greater information.

The more noticeable change was that there was a large increase in the probability that the distributor was a trader by occupation in the bidding areas, relative to both the information-only and pure control group, suggesting that the distribution was more likely to be run by individuals that have skills relevant to distributing Raskin, even if they are “elites” (Column 5).

In Table 2, Panel B, we explore several characteristics of the individuals who are distributing Raskin. The new distributors are more likely to have a personal savings account for business, which suggests that they have some financial access necessary for handling the copayments involved in the process (Column 5). However, we find no difference in the propensity to own a truck or boat, no difference in score in a digit span test (e.g. ability), no difference in education level, and no difference in dice score points (e.g. a measure of dishonesty) for distributors in bidding and information areas (Columns 1-4).

In short, while the bidding treatment changed the identity of those distributing Raskin, it largely redistributed the role within the existing local government elite. However, within the elite, it reallocated the job to people with the relevant experience as a trader and capital. 


\section{B. Impact on program outcomes}

The next question is whether the bidding process led to a change in actual program functioning, as well as satisfaction with the process (Table 3). Using the household-level survey data, we estimate the same equation as in Table 2 using OLS. We now cluster standard errors to account for fact that the randomization was conducted by locality. We also control for the baseline value of the outcome variable in all regressions except rice quality in Column 4 , for which we lack baseline data. ${ }^{15}$

Before we turn to the results, note two important aspects regarding the interpretation of the findings. First, we estimate the intent-to-treat effects, rather than the IV impact on those locations where there was a new winner. This is because the act of having to compete for the distribution rights may have changed the outcomes, even if the old distributor won the distribution. Second, as neither the bidding nor information treatment had an effect on the relative propensity to buy Raskin rice across eligible and ineligible households, nor on the relative total quantities bought, we pool eligible and ineligible households. Thus, the regressions provide results for all citizens, regardless of eligibility status. ${ }^{16}$

As shown in Table 3, we find that the bidding treatment led to a reduction in the Raskin co-pay price, which as we discuss below was the key dimension that bidders competed on. We observe a Rp. 49/kg reduction in price markup relative to the information-only treatment (statistically significant at the 5 percent level): this constitutes about an 8 percent reduction in the markup charged (Column 2).

One worry is that to compensate for the lower price, more rice would go missing. This may particularly be the case because as the central government had mandated that distributors were supposed to provide the correct quantity of rice-and provide it to eligible households — this was not a category in the application form for the bid. Thus, this was not a criterion in which bidders were evaluated, even though correct distribution is important in practice. Put another way, since all distributors were in theory

\footnotetext{
${ }^{15}$ Appendix Table 7 replicates Table 3 omitting the baseline controls. The results are qualitatively similar.

${ }^{16}$ In Appendix Table 8A and 8B, we disaggregate Table 3 by eligibility status and show that findings are qualitatively similar, regardless of who bought the Raskin rice (but greater precision in estimates for eligible households in terms of price changes).
} 
supposed to distribute all the rice, it was not possible for bidders to compete on this dimension. In any case, the overall quantity of rice bought did not change (Column 3).

The key concern articulated by the HSV theory is that, as a result of outsourcing, private distributors may shirk and reduce non-contractible dimensions of quality. In our case, a key dimension is rice quality. Distributors can increase quality by refusing to accept low quality deliveries from the warehouse or by stopping a practice of selling high quality rice on the market and substituting lower quality rice for Raskin. Quality is non-contractible in this context: measurement of quality is fairly subjective (i.e., does the rice smell bad?) and distributors can blame quality problems on the central government warehouse. Thus, we asked households to assess the rice quality (Column 4). We observe an increase in their assessments of quality - about 3.7 percent higher compared to information only and about 4.9 percent higher than the pure control (p-value $<0.01) .{ }^{17}$

Looking at other dimensions, such as physical distance to purchase point, time needed to get to that point (which may differ from distance depending on road quality and other roadblocks), or whether the households paid for rice in advance (Columns 5-7), we do not find that these measures of quality worsened to compensate for the price change. If anything, households report that the time to travel to pick up the rice falls (Column 6). Finally, we examine changes in overall satisfaction with the Raskin process across the treatment groups (Column 8). Overall satisfaction with the program actually fell in the information treatment as citizens learned more about how the process should really look, with no additional difference for just the bidding process.

Overall, we observe a decrease in the price mark-up and an increase in quality, implying that allowing for competition through the bidding process, on average, improved the Raskin program.

\section{Impact on Distribution Costs}

As HSV theoretically point out, contracting out may lead to efficiency gains. To investigate this, at the endline, we interviewed the distributor (whomever it was) and asked about their distribution costs. Note

\footnotetext{
${ }^{17}$ In fact, in the bidding locations, households reported that the rice had fewer stones, an act of malfeasance by distributors to make the rice appear heavier than it really is.
} 
two aspects of the cost measures. First, they are self-reported; given the informal nature of the economy, one cannot track them through credit card or bank transactions. Nevertheless, they may shed light on how the distributers functioned. Second, the reported costs often increase in the information treatment relative to the pure control, likely because it forces distributors to have better compute their actual costs (and because they may be constrained to make sure the costs add up to the total markup) or because the greater scrutiny forces them to report their true costs. Given this, it is important to compare bidding and information to information only, rather than to pure control, to hold this transparency effect constant.

Table 4 shows that, indeed, we observe a decrease in transportation costs in the bidding treatment overall, relative to just pure information (Column 1). This is consistent with the view suggested by HSV that contracting out government services can lead to efficiency improvements and the overall view that privatization can improve performance (see Megginson and Netter 2001 for a review). We also observe total costs falling (Column 4) by about 25 percent, and though this is not statistically significant at conventional levels (p-value 0.133), it suggests that the overall process became more efficient.

\section{D. $\quad$ Selecting Among Bidders}

Selecting among bidders is complex. To the extent that there are non-contractible dimensions of quality, those running procurement procedures may wish to use characteristics that predict quality, such as a bidder's reputation or other potential performance indicators. One may also be concerned that bidders may attempt to renegotiate ex post if the winner cannot be forced to honor his original proposal; indeed, such renegotiations may be optimal in order to share risk if there is some information about the job that is only revealed ex-post. But, if renegotiations are allowed, a firm might adopt the strategy of bidding low to win the bidding and ask for better terms later (or abandon the job), ultimately leading to higher costs (Chang, Salmon and Saral, 2013; Decarolis 2014). ${ }^{18}$ Others (e.g. Gil and Oudot (2009)) have

\footnotetext{
${ }^{18}$ To avoid this possibility the US Department of Defense allows unrealistic bids to be rejected before implementing the first price auction, while other government agencies in the United States and Europe use an Average Bid Auction, where the bidder who is the closest to the average of the bids wins, though this can also facilitate collusion.
} 
recommended abandoning bidding altogether and negotiating with firms. ${ }^{19}$ There may also be incompetence or laziness among those running the bidding, or even outright corruption (see, for example, Bandeira, Pratt, and Villetti, 2009; Tran 2011; Sukhtankar 2015). Given these complexities, there is no guarantee that the right mechanism will be chosen, especially if the decision-making body has no special expertise in designing it.

Although we have seen that, on net, the bidding process improved outcomes, it is instructive to examine what committees actually did with the bids they received - i.e. did they essentially choose based on price, or did they consider other factors that may predict performance? And if so, could this help explain why they were not plagued by quality problems often associated with outsourcing? Therefore, we start by comparing winning (Column 1) and losing bids (Column 3) in Table 5 . In Column 5, we present the p-value of the difference between the two; note that this is clustered by location.

Winning bids look different than the losing ones on numerous dimensions. On average, the winners propose a lower mark-up on the co-pay price (Rp. 472/kg) than the losers (Rp. 567 /kg); this 17 percent difference is significant at the 1 percent level. The average winning bid proposed a mark-up that was about 28 percent lower than the baseline mark-up of Rp. 654/kg. These averages mask considerable heterogeneity. Appendix Figure 4 shows the winning price mark-up, by average baseline markup as reported by households. Most winning bids propose a mark-up that is below the baseline, particularly in areas where the mark-ups were initially very high. However, in areas where the mark-up was initially low, some winning bids propose higher prices; in these cases, the winners were more likely to propose other amenities, such as delivering straight to the households.

The winners also promised to transport the rice closer to citizens, promising that they would bring the rice directly to the numerous hamlets rather than one central location. On the other hand, the winners wanted households to pay for the rice upfront (44 percent upfront vs. 39 percent during delivery) relative to the losers (36 vs. 47 percent), presumably for their own assurance that they would recover their costs.

\footnotetext{
${ }^{19}$ However, Bulow and Klemperer (1996) show that an auction with $\mathrm{N}+1$ bidders always yield higher revenues than negotiations with $\mathrm{N}$ possible providers. Their result covers a wide class of auction mechanisms, but the possibility of ex post default by the winner of the auction is not considered.
} 
Table 5 includes all bids, regardless of whether or not there was more than one bid. To more formally analyze how bidding committees selected among bids, we restrict our sample to areas with multiple bids and estimate a conditional logit discrete choice model in Table 6. In Column 1, we explore each bid characteristic one by one on the probability winning (i.e., each cell reports the result from a separate regression). In Column 2, we include all bid proposal characteristics jointly, and in Column 3, we also add the individual characteristics of the bidder to the specification in Column 2.

As shown in Table 6, the proposed price is a significant predictor of winning, even conditional on other proposal (Column 2) or individual characteristics (Column 3), further implying that price enters strongly into the decision rule. In fact, the lowest bidder wins 82 percent of the time. Being the distributor at the time of bidding is also advantageous (Column 1), but the effect becomes smaller in magnitude and insignificant when controlling for proposal characteristics, suggesting that this advantage is driven by being able to propose a more attractive bid, rather than an incumbency advantage per se.

There is also evidence that, even conditional on price, the committees select bidders with skills that may make them more effective distributors. Specifically, bids that come from traders have an advantage, even conditional on other bid characteristics. The committee also appeared to choose winners who had access to transportation that could be used to distribute, were more educated, and had a savings account that can be used for business (Column 1). Note, however, these are no longer significant at conventional levels once you control for other characteristics such as being a trader, in Column 3.

These effects are quantitatively large and suggest that bidding committees are willing to pay substantially for distributors with these characteristics. Dividing the coefficient on 'being a trader' in Column 3 by the coefficient 'price' yields a willingness to pay for a trader: Rp. 247/kg or 30 percent of the control mean. Having access to transportation is similarly worth about Rp. 140/kg in additional markup. On net, these results suggest that the decision processes are not captured by incumbents; instead, they seem to largely select based on price, with some deviations that favor those with relevant experience or capital. One possible explanation for this is these choices is that bidding committees are attempting to 
solve the quality problem by choosing those with low unobserved costs or high skills, with the idea that conditional on their bid they may deliver higher quality.

\section{E. How does increased competition matter?}

The results thus far focus on the extensive margin - does the incumbent face any competition. We next use our additional minimum number of bidders to treatment to isolate the intensive margin of additional competition, conditional on the bidding process being held. Specifically, when the process becomes more competitive, is there a winner's curse in which the winners are firms that bid too low and who then renege (as in Bulow and Klemperer 2002)? Or, do bidding committees adjust their bidding rules in other dimensions, potentially to avoid a winner's curse problem?

To examine this question, recall that in a randomly-selected half of bidding locations, the bidding committee and the incumbent were informed at the start of the process that the bidding deadline would be extended if fewer than 3 bidders bid in the initial bidding period. As shown in Table 1, this generates a randomly-induced increase of about 30 percent in the number of bids - from a mean of 2.14 bids in bidding locations without this rule to 2.74 in areas with this rule.

Table 7 examines how this extra induced competition changed the prices in the bids, controlling for the baseline markup. While standard auction theory suggests that bidders in a sealed-price, first-price auction should bid more aggressively if they expect more bidders (e.g. Milgrom and Weber 1982), we find no evidence of this in our context. Specifically, in Columns 1 and 2, we find no evidence that the incumbent reduced their bid in response to the minimum number of bidders treatment, and in fact the point estimates are positive, albeit noisy. Columns 3 and 4 show that the average bid also did not change. Even more surprisingly, Columns 5 and 6 show that the minimum price bid did not change.

Nevertheless, we find that increased competition led to improved outcomes - largely because winners channeled cost reductions into lower prices for consumers. Table 8 re-examines the basic results

in Table 3, separately for the minimum number of bids and open bids treatments, showing that most of the effect on price was driven by the minimum number of bidders treatment: the minimum bidding 
treatment led to a Rp. 74/kg reduction in markup (11 percent), compared to only Rp. 24/kg for the open bidding treatment $(\mathrm{p}=0.06)$. Moreover, the quality increase occurred equally across both types of locations, so this reduction in price did not come at the expense of quality.

Table 9 examines the impacts on bidder's cost structure based on the minimum number of bids treatment. Both bidding treatments lead to a similar reduction in transportation costs (the p-value of comparing open versus minimum bid is 0.396). However, the minimum bid treatment also led to a reduction in payments to others and total other costs, whereas the bidding treatment without it did not. All of this combined (Column 4), the net effect of bidding with minimum number of bidders was a substantial reduction in costs, whereas the net effect of bidding without a minimum number of bidders was no change (p-value of difference 0.01$)$. One potential interpretation of these results is that either bidding treatment selected a more efficient supplier (i.e. one with lower actual transportation costs), but without the minimum number of bidders requirement, the winning bidder was able to offset this efficiency gain by not changing the price relative to the pure controls nearly as much, and instead captured these efficiency gains through the nebulous 'payments to others' category.

Combined these results present a bit of puzzle: how could outcomes improve even though, as shown in Table 7, bids did not perceptively change? Table 10 suggests that the difference comes from the bidding committee's decision rule. Specifically, we re-estimate Table 6, interacting each variable with the minimum bids treatment. In the minimum number of bids treatment, we find that citizens prefer the candidates who promise that they do not have to pay before receipt, and those with trading experience and transportation access, but do not find an observable difference in choosing on price mark-up. Thus, the increase in competition seems to allow committees to exercise preferences over aspects of the bid other than pure price. With more choice, bidding committees appear to choose a candidate who is more reliable on other dimensions for the same promised price, and that these candidates actually deliver on what they promise, rather than ex-post reneging and channel profits to amorphous 'payments to others' (Table 4). 


\section{Eliminating or Protecting Rents?}

The results thus far showed that introducing the opportunity to outsource improved outcomes, on both contractible dimensions (e.g. price) and non-contractible dimensions (e.g. quality of the rice). However, the magnitudes were not enormous - introducing the opportunity to outsource induced only 17 percent of locations to switch to a new distributor, prices fell by only 4.6 percent, and subjective quality assessment of the rice improved by 0.02 on a scale from 0 -1. Increasing competition on the intensive magnitude increased these magnitudes somewhat, but they are still not overwhelming.

As suggested by Figure 1, there are numerous reasons why locations may not have switched distributors. Some places refused to hold the bidding process; others had only 1 bid; in others, sometimes there were multiple bidders but the incumbent won; and in yet other cases, a new bidder won but was not allowed to take over the process. All of these activities could be a sign that things are working well maybe nobody bids when the incumbent is the lowest-cost supplier, or the incumbent is chosen because he is doing a great job. Or they could be an indication of vested interest blocking the process to protect their rents - intimidating others from bidding, influencing the selection committee, and so on.

To examine these issues, we explore heterogeneity analysis in how the treatment worked - both in terms of these various blocking behaviors an in terms of the ultimate outcome of the program - as a function of the Raskin co-pay price at baseline, as well as other program metrics. Although the price of Raskin includes real transportation costs, it also is a likely proxy to some extent for rents being obtained from the system. ${ }^{20}$ To see if this is the case, Table 11 examines the correlation of the Raskin price at baseline (Columns 1 and 2) and the Raskin price at endline in our control areas (Column 3-5), controlling for local characteristics that proxy transportation costs (e.g. distance to the subdistrict, log population, and number of hamlets). ${ }^{21}$ Higher price is not only strongly correlated with citizen perceptions of corruption, but it is also positively correlated with the distributors scoring higher than median on the experimental

\footnotetext{
${ }^{20}$ Looking at our control villages, the Raskin price is correlated with villager's perception of how corrupt the village head and Raskin distributor are (see Table 11). Of course, this is not dispositive - it may be just that villagers infer there is corruption when they see a high price - but it is nonetheless suggestive.

${ }^{21}$ Results are similar without controls; see Appendix Table 12.
} 
dice-based dishonesty task. This suggests that the baseline price may indeed capture not just transportation costs, but also the amount of rents in the system.

Table 12 begins by investigating ex-ante blocking - i.e. of the 191 locations randomized to bidding, in which types of areas did bidding actually occur? We regress a dummy variable that equals 1 if there was no bidding meeting or no bids at the meeting on local characteristics. Each cell in Column 1 comes from a separate regression; Columns $2-4$ report the results from a single regression in each column. ${ }^{22}$ Higher prices predict the occurrence of a contested meeting: a one standard deviation increase in baseline markup (Rp. 427) would increase the odds by 0.30 . Part of this may be entry, as Figure 1 shows a virtually monotonic pattern between the baseline price and the number of bids. However, it may also be driven by demand - locations with low baseline satisfaction are more likely to hold a contested meeting, even conditional on price. On the other hand, locations where the baseline distributor had a high dishonesty score (measured by the dice task) were less likely to have a contested meeting. Combined, this suggests the presence of both offsetting effects: high baseline rents may encourage new entrants and increase demand for outsourcing, but corrupt incumbents may also seek to obstruct the process.

The next set of results in Table 12 investigates the probability that the incumbent distributor was chosen as the winner, conditional on the bidding process occurring (i.e. conditional on it not being blocked in the first stage; results defined for all 191 treatment locations are available in Appendix Table 13). The incumbent is less likely to be chosen when baseline prices were high, though the results are about a third of the magnitude as in the previous table. The incumbent is also more likely to be chosen when baseline household satisfaction is high. ${ }^{23}$ Dishonest incumbents (as measured by dice score) are more likely to win - another stage at which corrupt elites may partially offset the forces of competition.

The final set of results in Table 12 examines whether the incumbent distributor is still distributing six months later, conditional on him not having won the bidding. This variable captures ex-post capture.

\footnotetext{
${ }^{22}$ Appendix Table 14 shows that the Table 12 results are robust to OLS estimation.

${ }^{23}$ Appendix Table 15 shows that these results are virtually unchanged when we control for objective characteristics that might predict how difficult or expensive it would be to deliver Raskin in the village, such as the number of hamlets in the village, log village population, and distance to the subdistrict (which is where the rice is often dropped off by the village government). Appendix Table 16 replicates 15, but for all treatment locations.
} 
Here, very little predicts action at this stage, suggesting that on average at least, most of the tussle over rents happens before and during the bidding, not after.

In contrast to the price, the total quantity bought was not predictive of whether the incumbent distributor won, even though reduced quantity to eligible households accounts for a large share of leakage. ${ }^{24}$ This is suggestive of the fact that households may view that the price is within the distributor's control, but that missing rice is not; it may also be because quantity was not explicitly listed on the forms.

Table 12 explores explicit blocking behavior in the treatment areas. However, we can also explore the heterogeneity of treatment effects by comparing differential effects across the treatment and control areas. Figure 2 plots non-parametric Fan (1992) regressions of several outcome variables against the baseline Raskin price markup. Since the information treatment outcomes were similar to the pure control and since non-parametric regressions are quite data-intensive, we focus on figures that show the estimated relationships between outcome and baseline markup for both bidding areas and the combination of information and pure control areas. Bootstrapped 95 percent confidence intervals are shown as dashed lines, and we include the 45 degree line for ease of comparison.

Figure 2, Panel A shows the endline price plotted against the baseline price in bidding vs information/control areas. In the bottom half of the price-mark-up distribution, we do not observe any treatment effect. The reduction in price instead appears to be driven from large declines higher up the baseline price distribution (i.e. between about Rp. 1,000/kg and Rp. 2,000/kg). This suggests that on net the treatment was most effective in more problematic areas, despite the fact that vested interests may have had more rents to protect. In Panel B, we look at the rice quality as reported by households; again, the bidding treatment seems to improve the program in areas with relatively high baseline prices.

Finally, in Panel C, we examine the probability that the endline distributor differs from the baseline. Overall, the probability of replacing the distributor slopes up in baseline price, signaling that

\footnotetext{
${ }^{24}$ This is not due to households having low demand for Raskin rice. When informed of their eligibility rights and quantity entitlements, households buy much more Raskin rice (Banerjee et al 2015).
} 
bidding committees generally retain low-price distributors. However, the bidding treatment seems to lead to a uniform increase in replacement - even in places with low markups where price does not change.

Combined, these results suggest that while the bidding treatment had positive effects in places where initial prices were high, there is one potential cost of allowing for private entrants: since the increase in the probability of changing distributors does not vary with the baseline price, but the program improvements are only in places with higher baseline prices, it suggests that the increased probability of replacing the distributor in areas with low baseline prices is inefficient. That is, when the program is working reasonably well, the bidding process still induces local governments to change distributors, even when this achieves no benefits. The results also suggest that the results may have been muted by corrupt elites working to protect their rents either ex-ante by preventing people from bidding or during the process by maneuvering to have themselves selected as the winner of the bidding.

\section{CONCLUSION}

In this paper, we examine whether allowing local governments to outsource the delivery to the private sector can improve the distribution. Focusing on a subsidized food distribution program, we show that allowing localities the ability to outsource last-mile delivery of subsidized food reduced its price, without sacrificing other aspects of the distribution quality to "pay” for these price reductions (if anything, it also improved rice quality). The price declines appear to come from both from greater efficiency in the form of lower transport costs and lower rents.

Exploring the channels that drive these effects, we document several important facts. First, it appear that-despite no particularly special expertise-the local governments were making broadly sensible choices, focusing mostly on reducing the price of the subsidized rice, but also giving weight to the relevant distributor characteristics that may be correlated with quality, such as having experience as a trader. Second, experimentally inducing even more competition through a minimum number of bids required to host the bidding process led to even greater efficiency gains and lower prices than in bidding 
areas where there was no requirement. This suggests that inducing greater competition can lead to improved outcomes, without leading to a winner's curse.

Overall, however, while the bidding process improved outcomes in the last-mile delivery of food distribution program, the effects were not quantitatively large - only 17 percent of locations were induced to switch distributors, and prices fell by only 4.6 percent on average. We document that while, on net, these improvements came from places where there were substantial rents at baseline, corrupt local officials - as measured by our experimental dice-based dishonesty measure, which we show is correlated with rents -- were able to mute these effects to some degree by blocking the process or preventing others from bidding. Taken together, this suggests while there can be gains from outsourcing, it is important to think about how we design these processes in contexts with strong vested interests.

\section{WORKS CITED}

Acemoglu, Daron, and James A. Robinson. "Political Losers as a Barrier to Economic Development.” American Economic Review 90 (2000): 126-130.

Alatas, Vivi, Abhijit Banerjee, Rema Hanna, Benjamin A. Olken, and Julia Tobias. "Targeting the Poor: Evidence from a Field Experiment in Indonesia.” American Economic Review 102, no 4 (2012): 1206-40.

Alatas, Vivi, Abhijit Banerjee, Rema Hanna, Benjamin A. Olken, Ririn Purnamasari, and Matthew Waipoi. "Self-Targeting: Evidence From A Field Experiment In Indonesia." Journal of Political Economy, forthcoming.

Bajari, Patrick, Robert McMillan, and Steven Tadelis. "Auctions Versus Negotiations in Procurement: An Empirical Analysis.” Journal of Law, Economics, and Organization 25, no. 2 (2009): 372-399.

Bajari, Patrick, and Steven Tadelis. "Incentives Versus Transaction Costs: A Theory of Procurement Contracts.” RAND Journal of Economics (2001): 387-407.

Bandiera, Oriana, Andrea Prat, and Tommaso Valletti, "Active and Passive Waste in Government Spending: Evidence from a Policy Experiment,” American Economic Review, 99 (2009), 1278-1308.

Banerjee, Abhijit, Rema Hanna, Jordan C. Kyle, Benjamin A. Olken, and Sudarno Sumarto. "The Power of Transparency: Information, Identification Cards and Food Subsidy Programs in Indonesia.” NBER Working Paper No. 20923 (2015).

Bresnahan, Timothy F., and Peter C. Reiss. "Entry and Competition in Concentrated Markets.” Journal of Political Economy (1991): 977-1009.

Bulow, Jeremy, and Paul Klemperer. "Prices and the Winner's Curse.” RAND Journal of Economics, 33 (2002): 1-21.

Busso, Marias and Sebastian Galiani, “The Causal Effect of Competition on Prices and Quality: Evidence from a Field Experiment,” NBER Workign Paper No. 20052 (2014).

Chang, Wei-Shiun, Tim Salmon, and Krista Jabs Saral. "Procurement Auctions with Renegotiation and Wealth Constraints.” MPA Working Paper No. 50137, 2013.

Decarolis, Francesco. "Awarding Price, Contract Performance, and Bids Screening: Evidence from Procurement Auctions.” American Economic Journal: Applied Economics 6, no. 1 (2014): 108-132.

Dearden, Lorraine, and Martin Ravallion. "Social Security in a 'Moral Economy': An Empirical Analysis for Java.” Review of Economics and Statistics, 70 (1988): 36-44. 
Fan, Jianqing. "Design-Adaptive Nonparametric Regression." Journal of the American Statistical Association 87, no. 420 (1992): 998-1004.

Fischbacher, Urs, and Franziska Föllmi-Heusi. "Lies in Disguise: An Experimental Study on Cheating,” Journal of the European Economic Association, 11 (2013): 525-547.

Gil, Ricard, and Jean-Michel Oudot. "Competitive Bidding, Renegotiation and Relational Contracting: Evidence from French Defense Procurement.” Working Paper (2009).

Government of Indonesia. 2012. "Nota Keuangan dan Rancangan Anggaran Pendapatan dan Belanja Negara Perubahan tahun anggaran 2012 [Financial Note and Revised Budget 2012]." http://www.perpustakaan.depkeu.go.id/ FOLDERDOKUMEN/Th.\%202012\%20perubahan.pdf

Gustafsson, Bjorn A and Deng Quheng. "Di Bao Receipt and Its Importance for Combating Poverty in Urban China.” Poverty \& Public Policy 3 (1), Article 10, (2011).

Hanna, Rema, and Shing-Yi Wang. "Dishonesty and Selection into Public Service: Evidence from India." NBER Working Paper No. 19649 (2015).

Hart, Oliver, Andrei Shleifer, and Robert W. Vishny. "The Proper Scope of Government: Theory and an Application to Prisons.” Quarterly Journal of Economics, 112 (1997): 1127-1161.

Hirsch, Werner Z. "Factors Important in Local Governments' Privatization Decision.” Urban Affairs Quarterly 31 (1995): 226-43.

Krusell, Per, and Jose-Victor Rios-Rull. "Vested Interests in a Positive Theory of Stagnation and Growth.” The Review of Economic Studies 63, no. 2 (1996): 301-329.

McEntee, Gerald W. "Privatization Isn't a Panacea.” Wall Street Journal, October 22, 1987.

Megginson, William and Jeffry Netter. "From State to Market: A Survey of Empirical Studies on Privatization.” Journal of Economic Literature 39 (2001): 321-389.

Milgrom, Paul R., and Robert J. Weber. "A Theory of Auctions and Competitive Bidding.” Econometrica (1982): 1089-1122.

Olken, Benjamin A. "Corruption and the Costs of Redistribution: Micro Evidence from Indonesia.” Journal of Public Economics 90, no. 4 (2006): 853-870.

Sukhtankar, Sandip. "The Impact of Corruption on Consumer Markets: Evidence from the Allocation of 2G Wireless Spectrum in India.” Journal of Law and Economics 58 (2015).

Spulber, Daniel F. "Auctions and Contract Enforcement." Journal of Law, Economics, and Organization (1990): 325-344.

Tran, Anh, "Which Regulations Reduce Corruption? Evidence from the Internal Records of a Bribepaying Firm”, mimeo, Indiana University (2011).

World Bank. "Raskin Subsidized Rice Delivery: Social Assistance Program and Public Expenditure Review.” Jakarta, Indonesia: Memo (2012). 
Table 1: The Bidding Process (Conditional on Bidding Meeting Occurring)

\begin{tabular}{|c|c|c|c|c|c|c|c|}
\hline & \multicolumn{2}{|c|}{ Overall } & \multicolumn{2}{|c|}{ Open Bids } & \multicolumn{2}{|c|}{ Min \# Bids } & \multirow{2}{*}{$\begin{array}{c}\text { P-Value } \\
\text { Open Bids = } \\
\text { Min \# Bids } \\
\text { (7) }\end{array}$} \\
\hline & $\begin{array}{c}\text { Mean } \\
(1)\end{array}$ & $\begin{array}{c}\text { Std. Dev. } \\
\text { (2) }\end{array}$ & $\begin{array}{c}\text { Mean } \\
(3)\end{array}$ & $\begin{array}{c}\text { Std. Dev. } \\
(4)\end{array}$ & $\begin{array}{c}\text { Mean } \\
(5)\end{array}$ & $\begin{array}{c}\text { Std. Dev. } \\
\text { (6) }\end{array}$ & \\
\hline \multicolumn{8}{|c|}{ Panel A: Bids Submitted } \\
\hline Number of Bids & 2.43 & 1.66 & 2.14 & 1.68 & 2.74 & 1.59 & $0.01 * *$ \\
\hline Number of Bids, After Initial Screening & 2.16 & 1.50 & 1.88 & 1.47 & 2.44 & 1.48 & $0.01 * *$ \\
\hline Old Distributor Wins & 0.52 & 0.50 & 0.49 & 0.50 & 0.55 & 0.50 & 0.49 \\
\hline \multicolumn{8}{|c|}{ Panel B: Meeting Attendance } \\
\hline Attendees & 21.69 & 9.13 & 21.09 & 10.31 & 22.31 & 7.75 & 0.36 \\
\hline Raskin Beneficiaries & 8.28 & 8.32 & 8.78 & 8.95 & 7.77 & 7.63 & 0.41 \\
\hline Local Officials & 9.42 & 5.83 & 8.80 & 5.95 & 10.06 & 5.66 & 0.14 \\
\hline \multicolumn{8}{|c|}{ Panel C: Meeting Participation } \\
\hline No Discussion at Meeting & 0.09 & 0.29 & 0.03 & 0.18 & 0.15 & 0.36 & $0.01 * * *$ \\
\hline$<10 \%$ of People Talk & 0.43 & 0.50 & 0.46 & 0.50 & 0.41 & 0.49 & 0.51 \\
\hline $10-50 \%$ of People Talk & 0.45 & 0.50 & 0.50 & 0.50 & 0.40 & 0.49 & 0.16 \\
\hline$>50 \%$ of People Talk & 0.03 & 0.16 & 0.01 & 0.11 & 0.04 & 0.21 & 0.18 \\
\hline
\end{tabular}

Notes: This table provides summary statistics on the number of bids submitted, as well as the attendance and participation during the bidding meeting. All data come from the forms that the facilitators used to document the bidding process. We first present the sample statistics for the 184 localities where a bidding meeting was held and then we disaggregate the data by whether the locality was randomly assigned to the minimum bid requirement (91 localities) or it was left open (93 localities). ${ }^{* * *} \mathrm{p}<0.01{ }^{* *} \mathrm{p}<0.05 * \mathrm{p}<0.1$. 
Table 2: Who Distributes Raskin Six Months After Intervention?

\begin{tabular}{|c|c|c|c|c|c|c|}
\hline \multicolumn{7}{|c|}{ Panel A: Distributor Identity and Connections } \\
\hline & $\begin{array}{l}\text { In charge of any } \\
\text { responsibilities } \\
\text { before May } 2013 \\
\text { (1) }\end{array}$ & $\begin{array}{c}\text { Distributor/spouse } \\
\text { is/was local official } \\
\text { (2) }\end{array}$ & $\begin{array}{c}\text { Distributor/spouse is } \\
\text { related to a local } \\
\text { official } \\
\text { (3) }\end{array}$ & $\begin{array}{c}\text { Distributor/spouse } \\
\text { is/was or is related to } \\
\text { hamlet official } \\
\text { (4) }\end{array}$ & $\begin{array}{l}\text { Is a trader } \\
(5)\end{array}$ & $\begin{array}{c}\text { Lives in locality } \\
\text { (6) }\end{array}$ \\
\hline Info or Bidding & $\begin{array}{l}-0.035 \\
(0.048)\end{array}$ & $\begin{array}{l}-0.059 \\
(0.050)\end{array}$ & $\begin{array}{c}0.043 \\
(0.044)\end{array}$ & $\begin{array}{c}0.038 \\
(0.055)\end{array}$ & $\begin{array}{c}0.008 \\
(0.027)\end{array}$ & $\begin{array}{l}-0.027 \\
(0.042)\end{array}$ \\
\hline Bidding & $\begin{array}{c}-0.165^{* * *} \\
(0.051)\end{array}$ & $\begin{array}{l}-0.076 \\
(0.053)\end{array}$ & $\begin{array}{c}0.046 \\
(0.047)\end{array}$ & $\begin{array}{c}0.043 \\
(0.058)\end{array}$ & $\begin{array}{l}0.071^{* *} \\
(0.028)\end{array}$ & $\begin{array}{l}-0.019 \\
(0.045)\end{array}$ \\
\hline P-Value & & & & & & \\
\hline Bidding $=$ Ctl & 0.000 & 0.001 & 0.013 & 0.063 & 0.000 & 0.175 \\
\hline Control Mean & 0.803 & 0.347 & 0.160 & 0.327 & 0.034 & 0.816 \\
\hline
\end{tabular}

\begin{tabular}{|c|c|c|c|c|c|}
\hline & $\begin{array}{c}\text { Owns a truck and/or } \\
\text { a boat } \\
(1)\end{array}$ & $\begin{array}{l}\text { Avg digit span above } \\
\text { median } \\
(2)\end{array}$ & $\begin{array}{c}\text { Raw dice score above } \\
\text { median } \\
(3)\end{array}$ & $\begin{array}{c}\text { Years of education } \\
(4)\end{array}$ & $\begin{array}{c}\text { Has personal savings } \\
\text { account for business } \\
\text { (5) }\end{array}$ \\
\hline \multirow[t]{2}{*}{ Info or Bidding } & -0.039 & -0.009 & -0.021 & 0.233 & 0.036 \\
\hline & $(0.026)$ & $(0.059)$ & $(0.059)$ & $(0.325)$ & $(0.055)$ \\
\hline \multirow[t]{2}{*}{ Bidding } & 0.022 & 0.002 & 0.023 & -0.453 & $0.105^{*}$ \\
\hline & $(0.028)$ & $(0.062)$ & $(0.062)$ & $(0.345)$ & $(0.058)$ \\
\hline \multicolumn{6}{|l|}{ P-Value } \\
\hline Bidding = Ctl & 0.432 & 0.875 & 0.963 & 0.397 & 0.001 \\
\hline Control Mean & 0.071 & 0.449 & 0.519 & 12.139 & 0.313 \\
\hline
\end{tabular}

Note: In this table, we explore the characteristics of bidders across the experimental groups, six months after the intervention. We regress each

characteristic on indicator variables for the bidding and information treatments and strata fixed effects. All regressions are estimated by OLS. Each column in each panel has 587 observations. *** $\mathrm{p}<0.01$, ** $\mathrm{p}<0.05,{ }^{*} \mathrm{p}<0.1$. 
Table 3: Raskin Distribution Process

\begin{tabular}{|c|c|c|c|c|c|c|c|c|}
\hline & $\begin{array}{c}\text { Bought Raskin } \\
\text { (1) }\end{array}$ & $\begin{array}{l}\text { Price markup } \\
\text { (2) }\end{array}$ & $\begin{array}{c}\text { Amount } \\
\text { purchased } \\
\text { (3) }\end{array}$ & $\begin{array}{l}\text { Satisfied with } \\
\text { rice quality } \\
\text { (4) }\end{array}$ & $\begin{array}{c}\text { Distance to } \\
\text { purchase point } \\
\text { (meters) } \\
\text { (5) }\end{array}$ & $\begin{array}{c}\text { Time to } \\
\text { purchase point } \\
\text { (minutes) } \\
(6)\end{array}$ & $\begin{array}{l}\text { Paid for rice in } \\
\text { advance } \\
\text { (7) }\end{array}$ & $\begin{array}{c}\text { Satisfied with } \\
\text { Raskin program } \\
\text { (8) }\end{array}$ \\
\hline \multirow[t]{2}{*}{ Info or Bidding } & -0.009 & 18.770 & 0.151 & 0.006 & -1.080 & 0.441 & 0.013 & $-0.020^{*}$ \\
\hline & $(0.02)$ & (24.07) & $(0.23)$ & $(0.01)$ & (14.37) & $(0.27)$ & $(0.02)$ & $(0.01)$ \\
\hline \multirow[t]{2}{*}{ Bidding } & 0.021 & $-49.023 * *$ & -0.002 & $0.019 *$ & 7.754 & $-0.501 *$ & -0.009 & 0.006 \\
\hline & (0.03) & $(24.91)$ & $(0.24)$ & $(0.01)$ & (15.15) & $(0.28)$ & $(0.03)$ & $(0.01)$ \\
\hline \multicolumn{9}{|l|}{ P-Value } \\
\hline Bidding $=$ Ctl & 0.55 & 0.09 & 0.39 & 0.00 & 0.55 & 0.75 & 0.82 & 0.06 \\
\hline Observations & 6,860 & 5,886 & 6,858 & 6,533 & 6,194 & 6,247 & 6,394 & 6,782 \\
\hline Control Mean & 0.76 & 652.39 & 5.76 & 0.51 & 190.96 & 5.94 & 0.43 & 0.59 \\
\hline
\end{tabular}

Note: This table explores the effect of the treatments on the actual program functioning. All data come from the household endline survey that we conducted about six months after the intervention. We regress each outcome on indicator variables for the bidding and information treatments, the baseline value of the outcome, and strata fixed effects. All regressions are estimated by OLS and standard errors are clustered by the locality. In Column 4, we do not control for baseline quality because we do not have this variable in the baseline survey. Columns 4 and 8 are categorical variables with 4 options on a scale of $0-1 .{ }^{* * *} \mathrm{p}<0.01,{ }^{* *} \mathrm{p}<0.05,{ }^{*} \mathrm{p}<0.1$. 
Table 4: Endline Costs to Current Distributor

\begin{tabular}{|c|c|c|c|c|}
\hline & $\begin{array}{c}\text { Transportation costs } \\
\text { (1) }\end{array}$ & $\begin{array}{l}\text { mpensation } \\
\text { others } \\
\text { (2) }\end{array}$ & $\begin{array}{c}\text { Other costs } \\
\text { (3) }\end{array}$ & $\begin{array}{c}\text { Total costs } \\
(4)\end{array}$ \\
\hline Info or Bidding & $\begin{array}{l}88,038 * \\
(52,052)\end{array}$ & $\begin{array}{c}121,875 \\
(174,163)\end{array}$ & $\begin{array}{l}40,716^{* *} \\
(18,745)\end{array}$ & $\begin{array}{c}318,287 \\
(211,403)\end{array}$ \\
\hline Bidding & $\begin{array}{c}-101,616^{*} \\
(54,924)\end{array}$ & $\begin{array}{c}-94,256 \\
(179,950)\end{array}$ & $\begin{array}{l}-30,531 \\
(19,678)\end{array}$ & $\begin{array}{l}-317,960 \\
(219,985)\end{array}$ \\
\hline \multicolumn{5}{|l|}{$P$-Value } \\
\hline Bidding = Ctl & 0.695 & 0.836 & 0.445 & 0.998 \\
\hline $\begin{array}{l}\text { Observations } \\
\text { Control Mean }\end{array}$ & $\begin{array}{c}574 \\
244,161\end{array}$ & $\begin{array}{c}574 \\
961,974\end{array}$ & $\begin{array}{c}574 \\
84,166\end{array}$ & $\begin{array}{c}574 \\
1.315,030\end{array}$ \\
\hline
\end{tabular}

Note: This table explores the effect of the treatments on the program costs (in Rp). All data come from the endline distributor survey that we conducted about six months after the intervention. We regress each outcome on indicator variables for the bidding and information treatments and strata fixed effects. All regressions are estimated by OLS with robust standard errors. If we have data for at least one cost variable, we replace missings with zeros for other cost categories. "Total costs" is the sum of Columns 1-3. The top one percentile of values for each cost are dropped. ${ }^{* * *} \mathrm{p}<0.01,{ }^{* *} \mathrm{p}<0.05,{ }^{*} \mathrm{p}<0.1$. 
Table 5: Comparison of Winning and Losing Bids in Bidding Treatment Localities

\begin{tabular}{lccccccc}
\hline \hline & \multicolumn{2}{c}{ Winners } & & \multicolumn{2}{c}{ Losers } & & \multicolumn{2}{c}{ P-Value } \\
\cline { 2 - 3 } & Mean & Std. Dev. & & Mean & Std. Dev. & Losers = Winners \\
& $(1)$ & $(2)$ & & $(3)$ & $(4)$ & & $(5)$ \\
\hline Price Markup (Rp/kg) Promised by Bidder & 471.62 & 270.20 & & 566.53 & 295.90 & & $0.00^{* * *}$ \\
Pay Before Receipt & 0.44 & 0.50 & & 0.36 & 0.48 & $0.04^{* *}$ \\
Pay During Receipt & 0.39 & 0.49 & & 0.47 & 0.50 & $0.03^{* *}$ \\
Pay After Receipt & 0.19 & 0.40 & & 0.20 & 0.40 & 0.74 \\
Raskin Distributed at Locality Level & 0.27 & 0.44 & & 0.32 & 0.47 & 0.15 \\
Raskin Distributed at Hamlet Level & 0.76 & 0.43 & & 0.68 & 0.47 & $0.01^{* *}$ \\
Raskin Distributed at Household Level & 0.03 & 0.17 & & 0.04 & 0.20 & \\
Bidder Offers Credit & 0.17 & 0.38 & & 0.15 & 0.36 & 0.37 \\
\hline \hline
\end{tabular}

Note: This table reports on various dimensions of bidder's proposals, by winning and losing bids (403 bids total). All data come from the application forms. Column 5 provides the $p$-value of the difference in mean between losers and winners, clustered by locality. ${ }^{* * *} \mathrm{p}<0.01 * * \mathrm{p}<0.05 * \mathrm{p}<0.1$ 
Table 6: Who was Selected in the Bidding Localities?

\begin{tabular}{|c|c|c|c|}
\hline & $\begin{array}{c}\text { 1-by-1 } \\
(1)\end{array}$ & $\begin{array}{c}\text { Joint (Form) } \\
(2) \\
\end{array}$ & $\begin{array}{c}\text { Joint (All) } \\
\text { (3) }\end{array}$ \\
\hline \multicolumn{4}{|c|}{ Panel A: Proposal Characteristics } \\
\hline Price markup (Rp/kg) promised by bidder & $\begin{array}{c}-0.010 * * * \\
(0.003)\end{array}$ & $\begin{array}{c}-0.009 * * * \\
(0.003)\end{array}$ & $\begin{array}{c}-0.007 * * * \\
(0.003)\end{array}$ \\
\hline Pay before receipt & $\begin{array}{l}-0.606 \\
(0.531)\end{array}$ & $\begin{array}{c}-0.614 \\
(1.170)\end{array}$ & $\begin{array}{l}-2.473 \\
(4.086)\end{array}$ \\
\hline Offers credit & $\begin{array}{c}0.731 \\
(0.599)\end{array}$ & $\begin{array}{c}1.148 \\
(0.743)\end{array}$ & $\begin{array}{c}1.021 \\
(0.816)\end{array}$ \\
\hline Lives in distribution locality & $\begin{array}{l}-1.207 * \\
(0.643)\end{array}$ & $\begin{array}{l}-1.029 \\
(1.054)\end{array}$ & $\begin{array}{c}-0.792 \\
(1.179)\end{array}$ \\
\hline Is Raskin distributor at time of bidding & $\begin{array}{l}0.531^{*} \\
(0.285)\end{array}$ & $\begin{array}{c}0.297 \\
(0.346)\end{array}$ & $\begin{array}{c}0.344 \\
(0.362)\end{array}$ \\
\hline Is a trader & $\begin{array}{l}1.120 * * \\
(0.527)\end{array}$ & $\begin{array}{c}2.303^{* * * *} \\
(0.714)\end{array}$ & $\begin{array}{c}1.734 * * * \\
(0.576)\end{array}$ \\
\hline $\begin{array}{l}\text { Has means of transportation supportive of Raskin } \\
\text { distribution }\end{array}$ & $\begin{array}{c}1.387 * * * \\
(0.422)\end{array}$ & $\begin{array}{l}1.295^{* * *} \\
(0.494)\end{array}$ & $\begin{array}{c}0.983 \\
(0.622)\end{array}$ \\
\hline \multicolumn{4}{|c|}{ Panel B: Individual Characteristics } \\
\hline Bidder/spouse is related to a local official & $\begin{array}{c}0.223 \\
(0.317)\end{array}$ & & $\begin{array}{c}0.035 \\
(0.358)\end{array}$ \\
\hline Bidder/spouse is/was local official & $\begin{array}{c}0.479 \\
(0.454)\end{array}$ & & $\begin{array}{c}0.115 \\
(0.702)\end{array}$ \\
\hline Raw dice score above median & $\begin{array}{c}0.197 \\
(0.279)\end{array}$ & & $\begin{array}{c}0.105 \\
(0.332)\end{array}$ \\
\hline Years of education & $\begin{array}{l}0.093 * * \\
(0.043)\end{array}$ & & $\begin{array}{c}0.008 \\
(0.055)\end{array}$ \\
\hline $\begin{array}{l}\text { Has personal savings account that be used for } \\
\text { business }\end{array}$ & $\begin{array}{l}0.849 * * \\
(0.356)\end{array}$ & & $\begin{array}{c}0.611 \\
(0.446)\end{array}$ \\
\hline Joint P-Value & & 0.000 & 0.010 \\
\hline
\end{tabular}

Note: In this table, we explore the characteristics that are associated with winning, in localities where there were multiple bids. For the sample of bids, we regress a dummy variable for whether the applicant was won on proposal and applicant characteristics, as well as locality fixed effects. We estimate all coefficients using a conditional logit and cluster the standard errors by locality. In Column 1, we estimate the effect of each characteristic individually. In Column 2, we estimate the joint effect of all proposal characteristics, while we additionally control for all individual characteristics in Column 3. Proposal characteristics come from the application forms, while individual characteristics come from the distributor survey that we conducted. ${ }^{* * *} \mathrm{p}<0.01, * * \mathrm{p}<0.05{ }^{*} \mathrm{p}<0.1$ 
Table 7: Bid Markups

\begin{tabular}{|c|c|c|c|c|c|c|}
\hline & \multicolumn{2}{|c|}{ Incumbent's Bid } & \multicolumn{2}{|c|}{ Average Bid } & \multicolumn{2}{|c|}{ Minimum Bid } \\
\hline & All Localities & $>1$ Bidder & All Localities & $>1$ Bidder & All Localities & $>1$ Bidder \\
\hline & (1) & (2) & (3) & (4) & (5) & (6) \\
\hline \multirow[t]{2}{*}{ Min \# Bids } & 10.435 & 3.360 & -4.842 & -13.886 & -1.788 & -0.996 \\
\hline & (46.351) & $(58.060)$ & (37.216) & $(41.760)$ & (32.012) & (38.558) \\
\hline \multirow[t]{2}{*}{ Baseline Markup } & $0.563 * * *$ & $0.556 * * *$ & $0.563^{* * *}$ & $0.556 * * *$ & $0.566 * * *$ & $0.560 * * *$ \\
\hline & $(0.074)$ & $(0.088)$ & (0.069) & $(0.076)$ & $(0.053)$ & $(0.060)$ \\
\hline \multirow[t]{2}{*}{ Constant } & $88.649 *$ & 108.682 & $129.450 * *$ & $148.947^{* *}$ & 57.352 & 60.637 \\
\hline & (53.424) & (68.749) & (51.027) & (58.434) & (39.338) & $(47.031)$ \\
\hline Observations & 146 & 110 & 412 & 362 & 165 & 115 \\
\hline R-squared & 0.436 & 0.423 & 0.405 & 0.397 & 0.487 & 0.489 \\
\hline
\end{tabular}

Note: This table compares bid markups between minimum bids and open bids treatment localities. Columns 1-2 report results on bids from distribution incumbents (if they exist), Columns 3-4 report average bids, and Columns 5-6 report minimum bid in a locality. Columns 1, 3, and 4 include all localities with at least one bid, while Columns 2, 4, and 6 restrict to localities with multiple bids. Results from OLS with a dummy for missing baseline markup. Robust standard errors in parentheses. ${ }^{* * *} \mathrm{p}<0.01,{ }^{* *} \mathrm{p}<0.05$, ${ }^{*} \mathrm{p}<0.1$ 
Table 8: Raskin Distribution Process, by Min \# Bids

\begin{tabular}{|c|c|c|c|c|c|c|c|c|}
\hline & $\begin{array}{c}\text { Bought Raskin } \\
\text { (1) }\end{array}$ & $\begin{array}{c}\text { Price markup } \\
\text { (2) } \\
\end{array}$ & $\begin{array}{c}\text { Amount } \\
\text { purchased } \\
(3) \\
\end{array}$ & $\begin{array}{c}\text { Satisfied with } \\
\text { rice quality } \\
(4) \\
\end{array}$ & $\begin{array}{c}\text { Distance to } \\
\text { purchase point } \\
\text { (meters) } \\
\text { (5) }\end{array}$ & $\begin{array}{c}\text { Time to } \\
\text { purchase point } \\
\text { (minutes) } \\
(6) \\
\end{array}$ & $\begin{array}{l}\mathrm{HH} \text { paid for } \\
\text { rice in advance } \\
(7)\end{array}$ & $\begin{array}{c}\text { Satisfied with } \\
\text { Raskin program } \\
\text { (8) }\end{array}$ \\
\hline \multirow[t]{2}{*}{ Info or Bidding } & -0.009 & 18.842 & 0.151 & 0.006 & -0.999 & 0.441 & 0.013 & $-0.020 *$ \\
\hline & $(0.02)$ & $(24.06)$ & $(0.23)$ & $(0.01)$ & (14.38) & $(0.27)$ & $(0.02)$ & $(0.01)$ \\
\hline \multirow[t]{2}{*}{ Open Bids } & 0.014 & -23.645 & -0.016 & 0.016 & 25.315 & -0.430 & 0.011 & 0.001 \\
\hline & $(0.03)$ & (29.94) & $(0.28)$ & $(0.01)$ & $(18.11)$ & $(0.33)$ & $(0.03)$ & $(0.01)$ \\
\hline Min \# Bids & $(0.03)$ & $(26.51)$ & $(0.27)$ & $(0.01)$ & $(16.62)$ & $(0.31)$ & $(0.03)$ & $(0.01)$ \\
\hline \multicolumn{9}{|l|}{ P-Value } \\
\hline Open = Min & 0.66 & 0.06 & 0.92 & 0.66 & 0.04 & 0.63 & 0.17 & 0.38 \\
\hline Open = Ctl & 0.84 & 0.84 & 0.55 & 0.05 & 0.10 & 0.96 & 0.29 & 0.06 \\
\hline $\operatorname{Min}=\mathrm{Ctl}$ & 0.46 & 0.01 & 0.44 & 0.01 & 0.44 & 0.57 & 0.52 & 0.29 \\
\hline Observations & 6,860 & 5,886 & 6,858 & 6,533 & 6,194 & 6,247 & 6,394 & 6,782 \\
\hline Control Mean & 0.76 & 652.39 & 5.76 & 0.51 & 190.96 & 5.94 & 0.43 & 0.59 \\
\hline
\end{tabular}

Note: This table explores the effect of the treatments on the actual program functioning. All data come from the household endline survey that we conducted about six months after the intervention. We regress each outcome on indicator variables for the bidding and information treatments, the baseline value of the outcome, and strata fixed effects, disaggregating the bidding effect by whether the locality was randomized into the minimum number of bids requirement or whether it was left open. All regressions are estimated by OLS and standard errors are clustered by the locality. In Column 4, we do not control for baseline quality because we do not have this variable in the baseline survey. Columns 4 and 8 are categorical variables with 4 options on a scale of 0 -1. *** $\mathrm{p}<0.01, * * \mathrm{p}<0.05, * \mathrm{p}<0.1$. 
Table 9: Endline Costs to Current Distributor, By Min \# Bids

\begin{tabular}{lcccc}
\hline \hline & $\begin{array}{c}\text { Transportation Costs } \\
(\mathrm{Rp})\end{array}$ & $\begin{array}{c}\text { Compensation to } \\
\text { Others (Rp) }\end{array}$ & $\begin{array}{c}\text { Other } \\
\text { Costs (Rp) }\end{array}$ & $\begin{array}{c}\text { Total Costs of } \\
\text { Distribution (Rp) } \\
\end{array}$ \\
$(1)$ & $(2)$ & $(3)$ & $(4)$ \\
\hline Info or Bidding & $87,943^{*}$ & 123,544 & $40,726^{* *}$ & 320,069 \\
& $(52,102)$ & $(174,286)$ & $(18,740)$ & $(211,657)$ \\
Open Bids & $-124,126^{* *}$ & 154,902 & $-13,578$ & $-51,869$ \\
& $(59,089)$ & $(222,663)$ & $(22,454)$ & $(263,152)$ \\
Min \# Bids & $-79,174$ & $-349,228^{*}$ & $-47,098^{* *}$ & $-590,262^{* * *}$ \\
& $(62,837)$ & $(180,668)$ & $(21,563)$ & $(223,414)$ \\
$P$-Value & & & & \\
Open = Min & 0.396 & 0.009 & 0.093 & 0.013 \\
Open = Ctl & 0.373 & 0.137 & 0.113 & 0.189 \\
Min = Ctl & 0.850 & 0.095 & 0.693 & 0.084 \\
Observations & 574 & 574 & 574 & 574 \\
Control Mean & 244,161 & 961,974 & 84,166 & $1,315,030$ \\
\hline \hline
\end{tabular}

Note: This table explores the effect of the treatments on the program costs. All data come from the endline distributor survey that we conducted about six months after the intervention. In Panel A, we regress each outcome on indicator variables for the bidding and information treatments and strata fixed effects, disaggregating the bidding effect by whether the locality was randomized into the minimum number of bids requirement or whether it was left open. All regressions are estimated by OLS with robust standard errors. If we have data for at least one cost variable, we replace missings with zeros for other cost categories. "Total costs of distribution" is the sum of Columns 1-3. The top one percentile of values for each cost are dropped. ${ }^{* * *} \mathrm{p}<0.01,{ }^{* *} \mathrm{p}<0.05,{ }^{*} \mathrm{p}<0.1$. 
Table 10: Who was Selected in Bidding Localities, by Min \# Bids?

\begin{tabular}{|c|c|c|c|}
\hline & $\begin{array}{c}\text { 1-by-1 } \\
(1)\end{array}$ & $\begin{array}{c}\text { Joint (Form) } \\
(2) \\
\end{array}$ & $\begin{array}{c}\text { Joint (All) } \\
(3)\end{array}$ \\
\hline \multicolumn{4}{|c|}{ Panel A: Proposal Characteristics } \\
\hline Min \# Bids * Promised price markup & $\begin{array}{c}0.002 \\
(0.006)\end{array}$ & $\begin{array}{c}0.005 \\
(0.008)\end{array}$ & $\begin{array}{l}-0.007 \\
(0.013)\end{array}$ \\
\hline Min \# Bids * Pay before receipt & $\begin{array}{l}-1.188 \\
(1.338)\end{array}$ & $\begin{array}{l}-4.470^{*} \\
(2.619)\end{array}$ & $\begin{array}{l}-62.377^{* * *} \\
(5.065)\end{array}$ \\
\hline Min \# Bids * Offers credit & $\begin{array}{l}-2.016 \\
(1.281)\end{array}$ & $\begin{array}{l}-1.141 \\
(1.830)\end{array}$ & $\begin{array}{l}-33.758^{* * *} \\
(2.989)\end{array}$ \\
\hline Min \# Bids * Lives in locality & $\begin{array}{c}12.896^{* * *} \\
(1.215)\end{array}$ & $\begin{array}{l}16.921^{* * *} \\
(2.801)\end{array}$ & $\begin{array}{l}8.911^{* * * *} \\
(3.370)\end{array}$ \\
\hline Min \# Bids * Distributor at time of bidding & $\begin{array}{l}0.830 \\
(0.577)\end{array}$ & $\begin{array}{l}1.006 \\
(1.023)\end{array}$ & $\begin{array}{c}1.191 \\
(1.236)\end{array}$ \\
\hline Min \# Bids * Trader & $\begin{array}{l}1.031 \\
(1.054)\end{array}$ & $\begin{array}{l}2.630^{*} \\
(1.539)\end{array}$ & $\begin{array}{c}20.489 * * * \\
(2.061)\end{array}$ \\
\hline $\begin{array}{l}\text { Min \# Bids * Has means of transportation } \\
\text { supportive of Raskin distribution }\end{array}$ & $\begin{aligned} 2.882^{* *} \\
(1.193)\end{aligned}$ & $\begin{array}{l}2.936^{* *} \\
(1.434)\end{array}$ & $\begin{array}{c}31.886 * * * \\
(1.767)\end{array}$ \\
\hline \multicolumn{4}{|c|}{ Panel B: Individual Characteristics } \\
\hline $\begin{array}{l}\text { Min \# Bids * Bidder/spouse is related to a local } \\
\text { official }\end{array}$ & $\begin{array}{c}0.723 \\
(0.654)\end{array}$ & & $\begin{array}{c}1.661 \\
(1.109)\end{array}$ \\
\hline Min \# Bids * Bidder/spouse is/was local official & $\begin{array}{l}1.503 \\
(0.984)\end{array}$ & & $\begin{array}{l}6.112^{* *} \\
(2.513)\end{array}$ \\
\hline Min \# Bids * Raw dice score above median & $\begin{array}{l}-0.255 \\
(0.568)\end{array}$ & & $\begin{array}{l}-0.611 \\
(0.838)\end{array}$ \\
\hline Min \# Bids * Years of education & $\begin{array}{c}0.059 \\
(0.088)\end{array}$ & & $\begin{array}{c}0.110 \\
(0.186)\end{array}$ \\
\hline Min \# Bids * Has personal savings account & $\begin{array}{c}0.309 \\
(0.721)\end{array}$ & & $\begin{array}{c}1.806 \\
(1.485)\end{array}$ \\
\hline Joint P-Value & & 0.000 & 0.000 \\
\hline
\end{tabular}

Note: In this table, we explore the characteristics that are associated with winning in localities where we imposed the minimum number of bids requirement as compared to those that were left often, in localities where there were multiple bids. For the sample of bids, we regress a dummy variable for whether the applicant was won on proposal and applicant characteristics, an indicator for the minimum number of bids requirement, the interactions of the characteristics with the dummy variable for the minimum number of bids requirement and locality fixed effects. We estimate all coefficients using a conditional logit and cluster the standard errors by locality. In Column 1, we estimate the effect of each characteristic individually. In Column 2, we estimate the joint effect of all proposal characteristics, while we additionally control for all individual characteristics in Column 3. Proposal characteristics come from the application forms, while individual characteristics come from the distributor survey that we conducted. ${ }^{* * *} \mathrm{p}<0.01,{ }^{* *} \mathrm{p}<0.05,{ }^{*} \mathrm{p}<0.1$ 
Table 11: Corruption on Locality Price Markup

\begin{tabular}{|c|c|c|c|c|c|}
\hline \multirow{4}{*}{$\begin{array}{l}\text { Raskin Distributor's Dice Score } \\
\text { Above Median }\end{array}$} & \multicolumn{2}{|c|}{ "Baseline Raskin Markup } & \multicolumn{3}{|c|}{ Endline Raskin Markup } \\
\hline & $(1)$ & $(2)$ & (3) & $(4)$ & (5) \\
\hline & $60.206^{*}$ & & $81.348^{* *}$ & & \\
\hline & (31.298) & & $(40.974)$ & & \\
\hline Perception of Local Head's & & $546.111 * * *$ & & $632.064^{* * *}$ & \\
\hline Corruption & & $(121.2$ & & $(179.4$ & \\
\hline Perception of Raskin & & & & & $647.773^{* * *}$ \\
\hline Distributor's Corruption & & & & & $(210.777)$ \\
\hline Observations & 454 & 562 & 282 & 283 & 273 \\
\hline \multicolumn{6}{|c|}{$\begin{array}{l}\text { Note: In this table, we explore the relationship between corruption and Raskin price markup. In each column, } \\
\text { we regress average price markup reported by households in a locality on a measure of corruption, controlling } \\
\text { for baseline locality characteristics (number of hamlets, log number of households, distance to subdistrict). Our } \\
\text { measures of corruption, by column, are: } 1 \text {. Dummy for baseline distributor's dice score above median; } 2 \text {. } \\
\text { Average perception of locality head's corruption at baseline; } 3 \text {. Dummy for endline distributor's dice score } \\
\text { above median; } 4 \text {. Average perception of locality head's corruption at endline; } 5 \text {. Average perception of Raskin } \\
\text { distributor's corruption at endline. Measures of corruption consist of } 4 \text { categories, scaled } 0-1 \text {, where } 0 \text { equals } \\
\text { "no possibility of corruption" and } 1 \text { equals "very high possibility of corruption." Columns } 1 \text { and } 2 \text { examine } \\
\text { baseline Raskin markup and include all localities; Columns } 3 \text {, } 4 \text {, and } 5 \text { examine endline Raskin price and } \\
\text { include control localities only. Robust standard errors in parentheses. } * * * p<0.01, * * p<0.05, * p<0.1\end{array}$} \\
\hline
\end{tabular}


Table 12: When Did Original Distributor Win and Continue Distributing?

\begin{tabular}{|c|c|c|c|c|c|c|c|c|c|c|c|c|}
\hline & \multicolumn{4}{|c|}{$\begin{array}{c}\text { Where Was No Bidding Meeting Held, or Meeting Had No } \\
\text { Bids? }\end{array}$} & \multicolumn{4}{|c|}{$\begin{array}{c}\text { Where Did Original Distributor Win? (Conditional on } \\
\text { Bidding Held with 1+ Bid) } \\
\end{array}$} & \multicolumn{4}{|c|}{$\begin{array}{c}\text { Where is Original Distributor Still Distributing? } \\
\text { (Conditional on Not Winning) }\end{array}$} \\
\hline & $\begin{array}{c}\text { 1-by-1 } \\
\text { (1) }\end{array}$ & $\begin{array}{c}\text { Joint } \\
\text { (Household } \\
\text { Only) } \\
(2) \\
\end{array}$ & $\begin{array}{c}\text { Joint (Form } \\
\text { Only) } \\
(3) \\
\end{array}$ & $\begin{array}{c}\text { Joint (All) } \\
(4)\end{array}$ & $\begin{array}{l}\text { 1-by-1 } \\
\text { (5) }\end{array}$ & $\begin{array}{c}\text { Joint } \\
\text { (Household } \\
\text { Only) } \\
(6) \\
\end{array}$ & $\begin{array}{c}\text { Joint (Form } \\
\text { Only) } \\
(7) \\
\end{array}$ & $\begin{array}{c}\text { Joint (All) } \\
\text { (8) }\end{array}$ & $\begin{array}{c}\text { 1-by-1 } \\
(9)\end{array}$ & $\begin{array}{c}\text { Joint } \\
\text { (Household } \\
\text { Only) } \\
(10) \\
\end{array}$ & $\begin{array}{c}\text { Joint (Form } \\
\text { Only) } \\
(11) \\
\end{array}$ & $\begin{array}{c}\text { Joint (All) } \\
(12)\end{array}$ \\
\hline \multicolumn{13}{|c|}{ Panel A: Reported by Households in Baseline } \\
\hline Avg Price Markup (Rp/kg) & $\begin{array}{c}-0.00299 * * * \\
(0.00089)\end{array}$ & $\begin{array}{l}-0.00291^{* *} \\
(0.00115)\end{array}$ & & $\begin{array}{l}-0.00337 * * * \\
(0.00122)\end{array}$ & $\begin{array}{c}-0.00115^{* *} \\
(0.00056)\end{array}$ & $\begin{array}{l}-0.00111^{*} \\
(0.00065)\end{array}$ & & $\begin{array}{l}-0.00141 \\
(0.00099)\end{array}$ & $\begin{array}{c}0.00017 \\
(0.00079)\end{array}$ & $\begin{array}{l}-0.00011 \\
(0.00090)\end{array}$ & & $\begin{array}{c}0.00062 \\
(0.00144)\end{array}$ \\
\hline HH Bought Raskin in Last 2 & 0.369 & 0.517 & & 0.285 & $1.598 * *$ & 0.995 & & 0.698 & -0.206 & 0.392 & & 1.493 \\
\hline Months & $(0.89)$ & $(1.24)$ & & (1.46) & $(0.65)$ & $(0.80)$ & & $(1.05)$ & $(0.87)$ & (1.13) & & (1.79) \\
\hline Avg Amount of Raskin & 0.0240 & -0.0429 & & -0.0615 & 0.0606 & -0.0031 & & 0.0223 & -0.0814 & -0.0694 & & -0.121 \\
\hline Purchased (kg) & $(0.068)$ & $(0.091)$ & & $(0.120)$ & $(0.071)$ & $(0.061)$ & & $(0.064)$ & $(0.071)$ & $(0.088)$ & & $(0.15)$ \\
\hline Avg Satisfaction with Program & $3.887^{*}$ & 1.408 & & 0.766 & $4.082 * *$ & $3.987 * *$ & & $5.981 * *$ & 0.524 & -0.042 & & 0.405 \\
\hline Quality (0-1 scale) & $(2.24)$ & (2.99) & & (3.37) & $(1.77)$ & $(1.9402)$ & & $(2.35)$ & (2.27) & (2.7635) & & $(4.23)$ \\
\hline $\begin{array}{l}\text { Avg Distance to Purchase Point } \\
\text { (meters) }\end{array}$ & $\begin{array}{l}0.00078 \\
(0.0013)\end{array}$ & $\begin{array}{l}-0.00070 \\
(0.0015)\end{array}$ & & $\begin{array}{l}-0.00030 \\
(0.0016)\end{array}$ & $\begin{array}{c}-0.00181^{*} \\
(0.0010)\end{array}$ & $\begin{array}{c}-0.00234^{*} \\
(0.0012)\end{array}$ & & $\begin{array}{c}-0.00300^{* *} \\
(0.0014)\end{array}$ & $\begin{array}{l}0.00163 \\
(0.0013)\end{array}$ & $\begin{array}{l}0.00182 \\
(0.0014)\end{array}$ & & $\begin{array}{l}0.00104 \\
(0.0018)\end{array}$ \\
\hline $\begin{array}{l}\text { HH purchased Raskin in } \\
\text { advance }\end{array}$ & $\begin{array}{c}1.47 * * * \\
(0.49)\end{array}$ & $\begin{array}{c}1.10^{* *} \\
(0.53)\end{array}$ & & $\begin{array}{l}1.20^{* *} \\
(0.61)\end{array}$ & $\begin{array}{c}0.80^{* *} \\
(0.38)\end{array}$ & $\begin{array}{c}0.24 \\
(0.42)\end{array}$ & & $\begin{array}{l}-0.11 \\
(0.51)\end{array}$ & $\begin{array}{l}-1.10^{*} \\
(0.63)\end{array}$ & $\begin{array}{l}-1.00 \\
(0.77)\end{array}$ & & $\begin{array}{l}-1.28 \\
(1.15)\end{array}$ \\
\hline \multicolumn{13}{|c|}{ Panel B: From Facilitation Forms } \\
\hline Raw dice score above median & $\begin{array}{l}0.81 * \\
(0.46)\end{array}$ & & $\begin{array}{l}0.95 * * \\
(0.48)\end{array}$ & $\begin{array}{l}1.01 * * \\
(0.49)\end{array}$ & $\begin{array}{c}0.98 * * * \\
(0.37)\end{array}$ & & $\begin{array}{l}0.98^{* *} \\
(0.39)\end{array}$ & $\begin{array}{l}0.87 * * \\
(0.43)\end{array}$ & $\begin{array}{c}-0.22 \\
(0.60)\end{array}$ & & $\begin{array}{c}-0.42 \\
(0.62)\end{array}$ & $\begin{array}{c}-0.66 \\
(0.66)\end{array}$ \\
\hline $\begin{array}{l}\text { Old Distributor Provides Credit } \\
\text { if Recipient Cannot Afford }\end{array}$ & $\begin{array}{l}-0.69 \\
(0.65)\end{array}$ & & $\begin{array}{l}-0.59 \\
(0.73)\end{array}$ & $\begin{array}{c}0.36 \\
(0.80)\end{array}$ & $\begin{array}{l}-0.26 \\
(0.39)\end{array}$ & & $\begin{array}{l}-0.11 \\
(0.56)\end{array}$ & $\begin{array}{c}0.24 \\
(0.66)\end{array}$ & $\begin{array}{c}0.34 \\
(0.56)\end{array}$ & & $\begin{array}{c}0.22 \\
(0.83)\end{array}$ & $\begin{array}{l}-0.44 \\
(0.96)\end{array}$ \\
\hline Costs of Rental Vehicle and/or & -0.0062 & & -0.0065 & $-0.0120^{*}$ & 0.0011 & & -0.0023 & -0.0000 & -0.0025 & & 0.0033 & 0.0047 \\
\hline Fuel to Old Distributor & $(0.0087)$ & & $(0.0081)$ & $(0.0070)$ & $(0.0036)$ & & $(0.0046)$ & $(0.0048)$ & $(0.0073)$ & & $(0.0071)$ & $(0.0076)$ \\
\hline Non-Transportation Costs to & -0.0003 & & 0.0004 & 0.0025 & -0.0013 & & -0.0008 & -0.0000 & -0.0021 & & 0.0003 & -0.0004 \\
\hline Old Distributor & $(0.0017)$ & & $(0.0014)$ & $(0.0016)$ & $(0.0012)$ & & $(0.0014)$ & $(0.0013)$ & $(0.0019)$ & & $(0.0027)$ & $(0.0033)$ \\
\hline Joint P-Value & & 0.004 & 0.294 & 0.006 & & 0.020 & 0.135 & 0.041 & & 0.546 & 0.962 & 0.540 \\
\hline Observations & & 187 & 149 & 147 & & 162 & 123 & 122 & & 76 & 55 & 54 \\
\hline Mean & & 0.13 & 0.17 & 0.17 & & 0.53 & 0.55 & 0.56 & & 0.32 & 0.33 & 0.31 \\
\hline
\end{tabular}




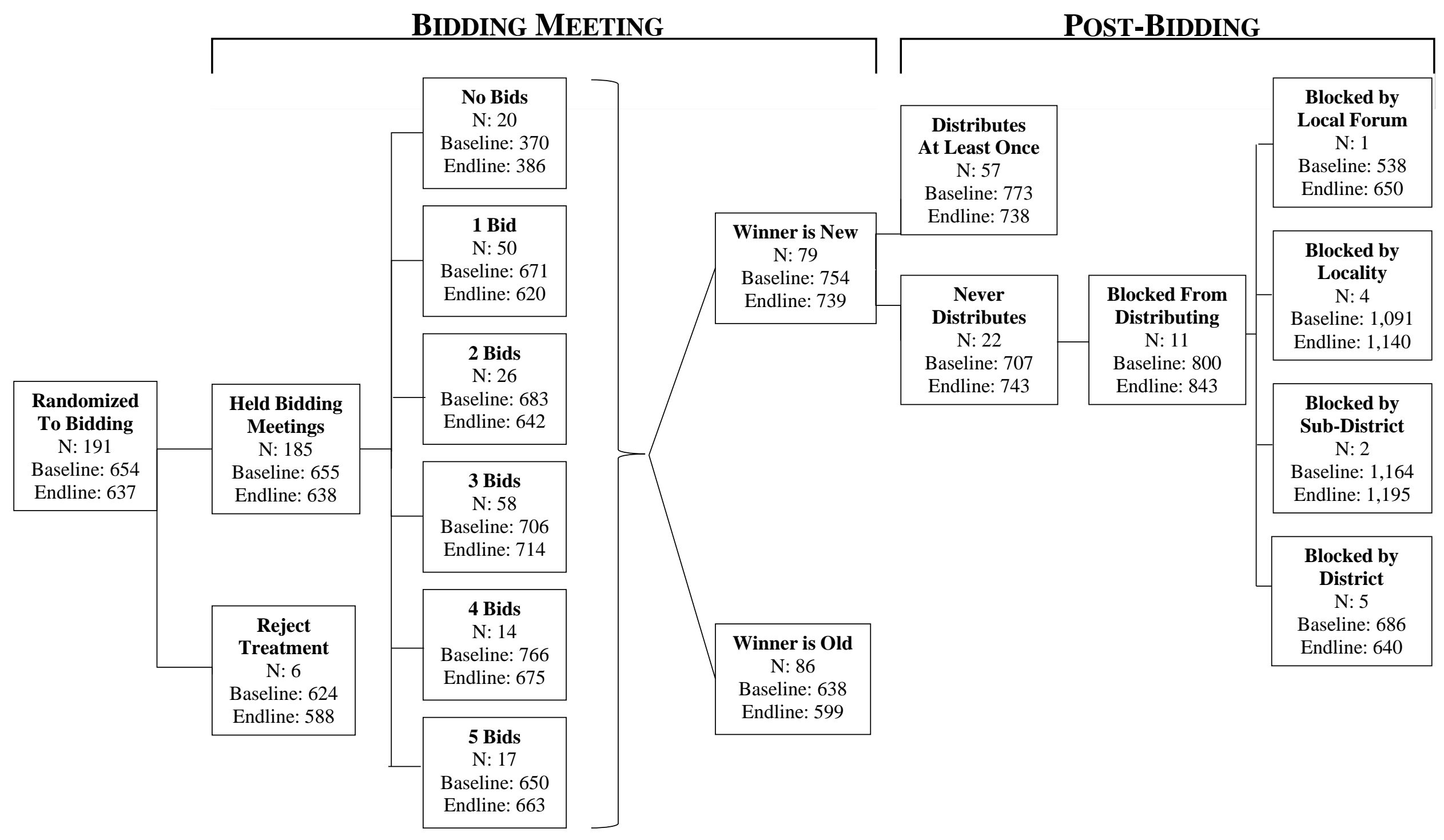


Figure 2: Non-parametric Estimations

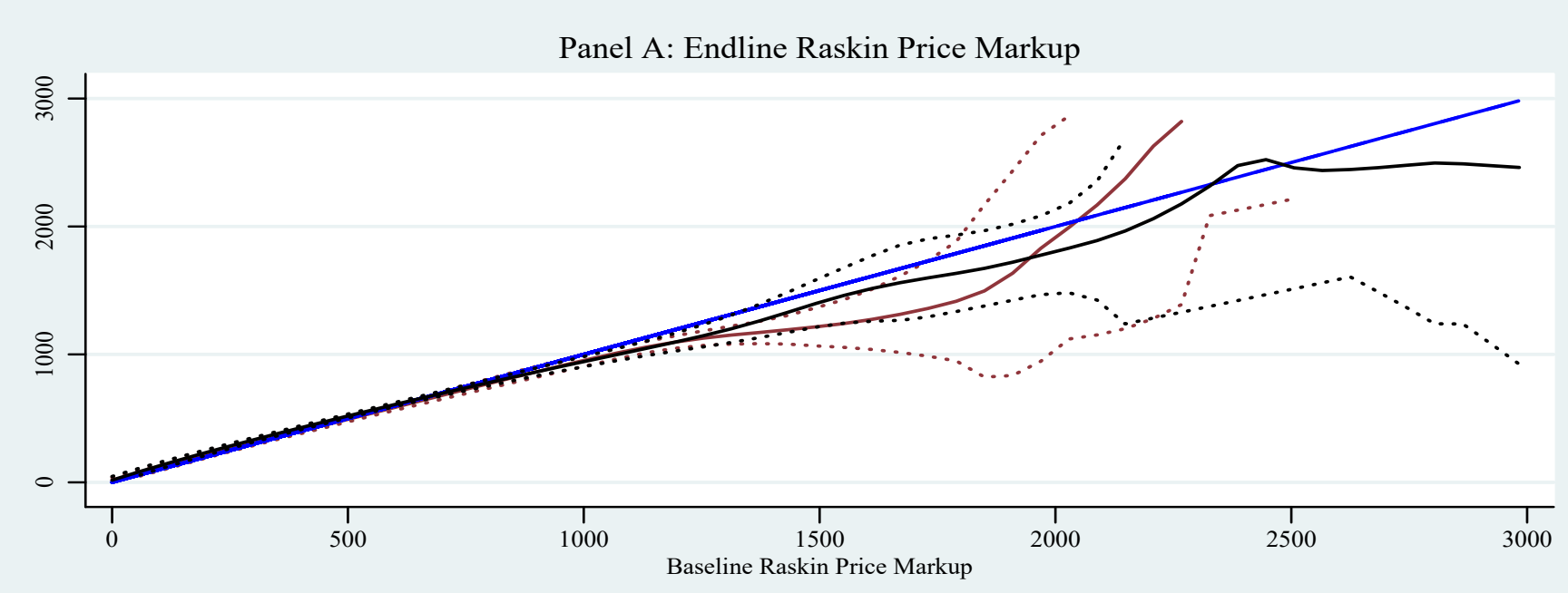

Panel B: Quality of Rice

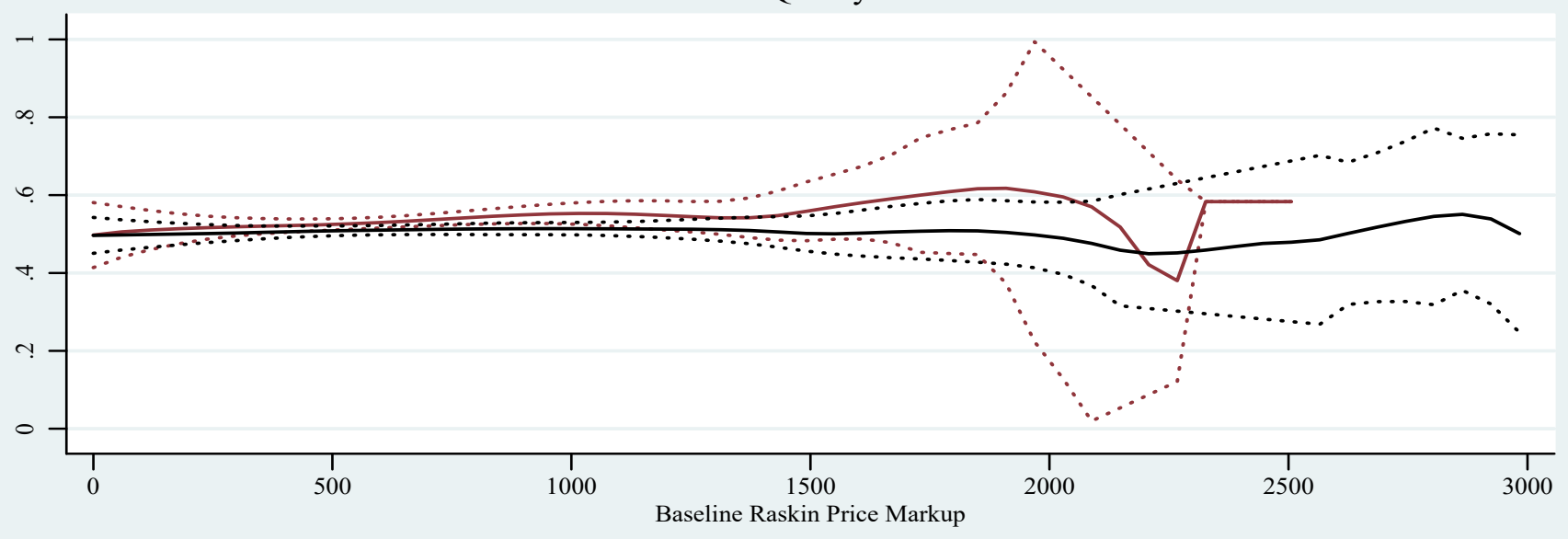

Panel C: New Distributor Chosen

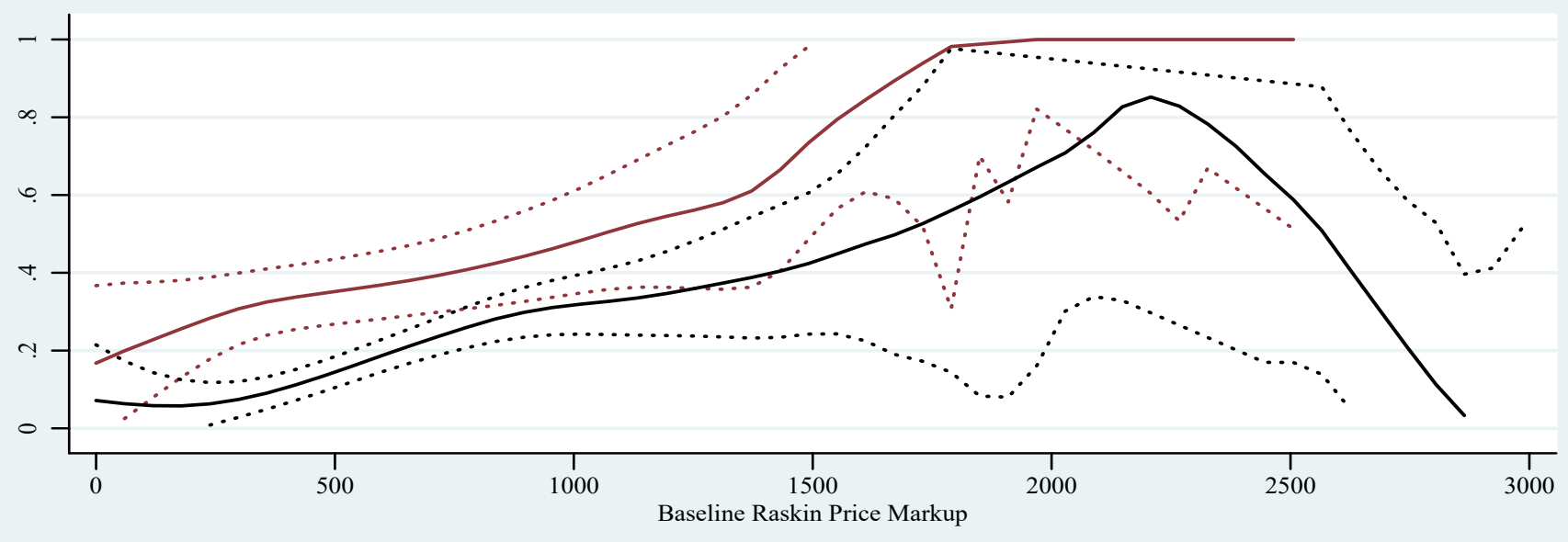

Bidding Control or Info

Bidding: CI $\quad$................ Control or Info: CI

-Bidding: CI $\quad \cdots \cdots \cdots \cdots \cdots \cdots$ Control or Info: CI

- - - - -45 Degree Line 
Figure 3: Endline Price Markup in Bidding Localities, By Results of Six-Month Re-Evaluation

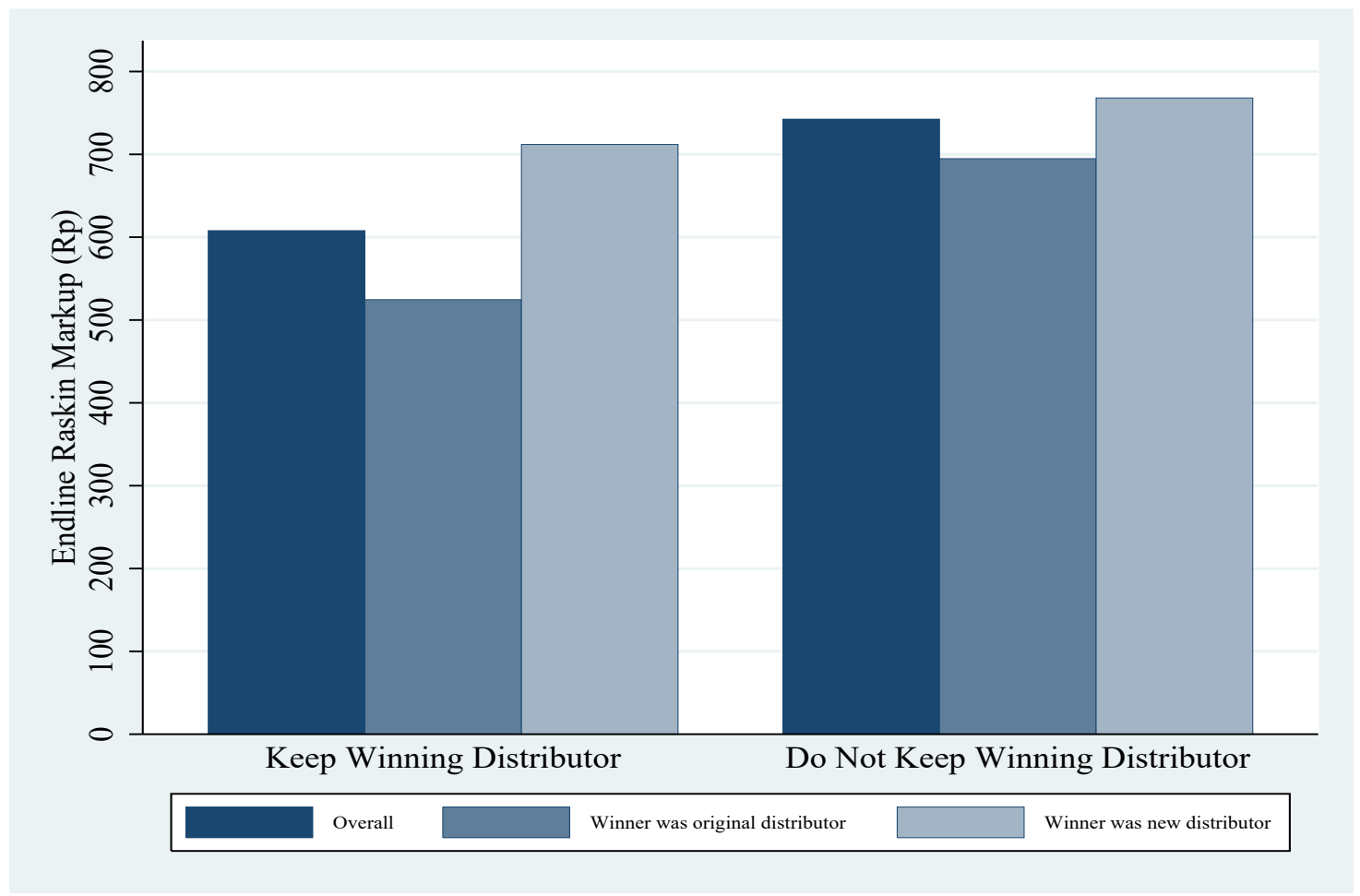

Notes: This figure gives average endline Raskin price markup (according to households) in bidding localities that held bidding meetings with at least one bidder. This is divided by (1) the results of the sixmonth re-evaluation and (2) whether the winning distributor was the same person as the original distributor (pre-bidding). 